\title{
Measuring Exterior Housing Quality in Four Older-Urban Neighbourhoods in Windsor, Ontario
}

\author{
Alan G. Phipps \\ Department of Sociology, Anthropology and Criminology, University of Windsor, Windsor, Canada \\ Email: phipps@uwindsor.ca
}

Received 26 November 2015; accepted 5 March 2016; published 8 March 2016

Copyright (C) 2016 by author and Scientific Research Publishing Inc.

This work is licensed under the Creative Commons Attribution International License (CC BY). http://creativecommons.org/licenses/by/4.0/

(c) (7) Open Access

\section{Abstract}

Four theoretically-deduced hypotheses about geographical and temporal variations in exterior housing quality within a neighbourhood are summarized as a renovation- or deterioration-of-self effect, a contagion-down-the-street effect, a distance-from-riverbank effect, and a distance-fromcore effect. These hypotheses are tested with data for the exterior conditions of hundreds of single-detached (-like) houses that have been individually surveyed twice with the same instrument in four older-urban neighbourhoods in Windsor, Ontario, Canada. Each surveyed house's rated conditions of 12 exterior attributes are in particular utilized to calculate its overall exterior quality as a percentage above or below normal. Findings are that houses' exteriors had average "normal" weathered conditions for Canada. Even so, overall exterior housing qualities in three neighbourhoods exemplified a hypothesized deterioration-of-self effect and proximity-to-core effect, as they had especially declined from their original survey to their resurvey for houses located near to a core such as downtown or a casino. In addition, the hypothesized distance-from-riverbank effect was observed in one neighbourhood where overall exterior housing quality linearly deteriorated with farther distance from a riverbank. Finally, overall exterior housing qualities had no observable contagion-down-the-street effect, and so, residents were not reacting positively or negatively to their neighbours' maintenance and improvement of their homes' exteriors. The practical implications of the study's findings are discussed in the conclusion.

\section{Keywords}

Home Maintenance and Improvement, Exterior Housing Quality, Home Attributes, Survey of Home Exterior, Older-Urban Neighbourhoods, Canada 


\section{Introduction}

One can infer a lot about the interior condition of a house from looking at its exterior when walking or driving by. For example, missing or torn shingles or clogged or broken eavestroughs at the top of the house may imply interior damage from seeping or dripping water. Older or plastic-covered windows or doors on the main levels may allow not only water penetration but also drafts inside the home. And a cracked foundation wall around the bottom, or inward-sloping ground within $2 \mathrm{~m}$ of it, may eventually produce water seepage and a settling foundation.

In other words, the visible exterior of a house provides numerous clues about the well-being of residents inside it [1]. The measurement of exterior housing attributes may have special value for planners and researchers if they do not want to bother residents with a personal questionnaire about its interior condition. The present study therefore attempts to explain where, when, and why houses will have different exterior qualities.

Four hypotheses about temporal and geographical variations in overall exterior housing quality are deduced from a theory about why residents may or may not maintain and improve their home's exterior. Home maintenance activities are generally defined in North America as those that counteract interior and exterior physical deterioration; whereas home improvements increase the housing stock without the construction of new dwellings [2]. Home maintenance may further be classified as non-discretionary repairs of broken vital parts of the home, as opposed to discretionary ones [3] —although exterior repairs of roof and windows, for example, may be less classifiable than interior ones of plumbing and heating. Either way, overall exterior housing quality should more frequently reflect the level of home maintenance than a home improvement that alters the exterior, such as by adding a room, or building a second story.

Note from the start that this study has neither questioned residents about the maintenance or improvement of their home's exterior; nor has it measured the comfort of those residents inside their homes (cf. [4]). Note furthermore the exclusion of low-rise row-houses, townhouses and apartments, some of which may be owned and operated by government or social organizations, and where residents will have a distinct social and economic relationship with the landlord who maintains their home [5].

This study's data for empirical analyses are from a walking paper-and-pencil survey of the visible conditions of twelve exterior attributes of up to 800 individual houses that have been surveyed twice in each of four older- urban neighbourhoods in Windsor, Ontario. Primarily of interest is a house's overall exterior quality as a percentage above or below "normal"; and the precise calculation of this percentage from a surveyor's ratings of twelve attribute conditions is illustrated below. The underlying research questions are accordingly, first, whether older-urban houses have normal exterior qualities that would make as livable for residents as elsewhere; and second, whether those with better or poorer exterior qualities have predictable temporal and geographical variations.

In general, a house has a "normal" overall exterior quality if its attributes have weathered- but serviceable-conditions for Canadian single-detached (-like) houses. This study's survey has been used exclusively in older-urban neighbourhoods, as higher proportions of houses with below-normal overall exterior qualities may be located there than elsewhere. Many residents in Windsor's older-urban neighbourhoods live in homes that in the early-1980s were eligible for grants and loans from governments for home maintenance and rehabilitation.

Now, however, even these Canadian older-urban homes may have reached the end of a forecasted 30-year extension in useful life. Structural deterioration of housing in particular neighbourhoods may again have three destabilizing social and economic effects as in the 1970s: 1) Older-urban residents will move out if they can move out. 2) Residents who could move in to replace them will avoid these areas. 3) Remaining older-urban residents will experience depleted housing, services and facilities, and so on [6].

\section{Why Individuals May or May Not Maintain and Improve Their Home's Exterior}

Beginning in the 1970s, new economic and environmental explanations of why residents and landlords would or would not maintain and repair their homes began to be published and empirically tested in the academic literature (e.g., [7] [8]). Empirical tests of these theoretical explanations coincided not only with new survey data of observed housing maintenance and improvement by residents and absentee owners (e.g., [9])—and some of these early surveys of housing quality are referenced in the next section. New theories and empirical tests also coincided with societal and governmental reconsideration of demolition and redevelopment of older-urban houses as an effective method of planning for them (e.g., [10]-[12]). Even aside from the social and environ- 
mental consequences, the private rehabilitation of existing modest housing should always be less expensive than the construction of new comparable housing [13] [14].

Subsequent studies have broadened the original economic and environmental explanations of housing maintenance and improvement to include social and psychological reasons as well. In addition, observations from large-scale quantitative surveys have been supplemented with individual surveys and qualitative analyses of respondents' activities in specific locations (e.g., [15]-[18]). Large-scale surveys in particular tended to ask respondents more about their expenditures on repairs or renovations, and less about their types of activities [9]. The present study therefore deduces its hypotheses of why individuals may or may not repair and renovate the exterior of a single-detached (-like) house from the more recent survey and qualitative literature.

Residents' and absentee owners' maintenance and improvement of their homes is normally explained as being motivated to maximize the home's current or future subjective value or utility subject to constraints [14] [19]-[21]. Individuals thinking about the utility of the home in terms of its flow of economic, environmental, social and psychological services should therefore invest their time and money into maintaining and improving those services it provides [22] [23]. New windows, doors and roof are not only functional but also cosmetic improvements of the home's visible exterior attributes.

Residents and owners will also consider their home's exchange value for themselves or their heirs [24], even though most evidently prioritize its use value in their maintenance and improvement activities [25]. They consequently should maintain or improve their home in an effort to prevent its depreciation and to increase its eventual sale price or market rent [26] [27]. New siding or brickwork on exterior walls may enhance the home's street appeal for potential buyers and renters, while somewhat increasing its energy efficiency [28].

Even so, most residents and absentee owners will inevitably be constrained from completing renovations at a planned speed to make them most satisfied with the home [29]. They may neither have the available time or handy skills to do major repairs or renovations themselves, nor the discretionary finances to pay for a contractor [30] [31]. They may be ineligible for either bank loans if interest rates are high, or the few available repairs grants [2] [32].

Moreover, different types of residents will have different perspectives about not only the utility derived from maintaining and improving their home, but also the constraints on them [9] [31] [33] [34]. For example, recent in-movers may have restrictive financial constraints, though being highly motivated to customize a new home for their household [35] [36]. In comparison, planning out-movers may invest in their current home solely to maximize its sale price [37]. In between, residents who are staying where they are living should routinely repair their home, although with a possibly-declining likelihood of improving it after 10- to 20-years of residence [38].

Stayer-residents in fact tend to spend more on maintaining and improving their homes during the middle stages of their life course [9] [34]. Besides more likely being owner-occupiers, they may have more money for discretionary expenses and/or proficient handy skills during that period of their working lives than do either residents just starting out, or those who have retired [30]. On the one hand, those with handy skills may still have to hire contractors for major repair and improvement work on the home's exterior, such as replacement of roof, walls, or multiple windows [30] [36] [39]. On the other hand, younger homeowners nowadays who distrust contractors may undertake presumably small-scale renovations by themselves, especially if they have a large household of wage-earners [18]. FYI, local contractors' approximate renovation and building costs are posted online at http://ontariocontractors.com/costs.htm.

\subsection{First Hypothesis: Renovation or Deterioration of Self}

Therefore, 1) if a home's exterior quality ultimately depends upon whether individuals do or do not care for it, a first hypothesis summarised as a renovation- or deterioration-of-self effect is that there will be differences in exterior housing quality between where some residents and owners have been willing and able to fix up their houses, and others have not. In particular in the absence of grants or financial assistance for home maintenance, overall exterior housing quality is more likely to be deteriorating than improving where residents are transitioning from mature owner-occupiers to absentee owners and younger renters or older owners.

\subsection{Second Hypothesis: Contagion down the Street}

Even while residents and owners will have their own reasons for maintaining or improving their home, they may be further encouraged or discouraged in their activities by the building's structure including construction mate- 
rials, its layout and design, and its single- or multiple-ownership [2] [40]; its location on a quiet or busy street, or far from or near to non-residential facilities; their municipality's rules about structural alterations in the form of building codes and zoning regulations [12]; and/or governmental financial “penalties” such as property tax reassessments [41].

Moreover, residents should also be sensitive to whether their neighbours are or are not maintaining and renovating their homes [8] [42]. This is because a major part of their home's utility could be derived from the nearby presence of friends and neighbours and their homes if located on a street in a community [43]. Thus, the effect of one neighbour's (in-)activity after another may almost spread contagiously down the street [16]. For example in Canadian older-urban neighbourhoods, multiple nearby homes may have new siding or windows if residents possibly notice neighbours' improvements after being prodded by salespersons. Conversely, under-maintenance of homes may be the communal reaction if neglected properties are clustered nearby, of which foreclosures are a recent example [44].

A positive contagious effect as opposed to negative one probably occurs if residents are more socially and economically similar inside a neighbourhood than they are city-wide. This in fact should be the norm if the neighbourhood remains the place for membership in religious and lay organizations, and schools [45]-[48]. Even cosmopolitan residents of older-urban neighbourhoods may have comparable neighbouring and spatial activities, and be satisfied with socio-economic diversity, non-traditional lifestyles, and local events [49].

Therefore, 2) if individuals’ maintenance of their home is influenced by what their neighbours are doing, then a second hypothesis summarised as a contagion-down-a-street effect will be for geographical clusters of well-maintained or poorly-maintained properties. Nearby houses should in particular have more similar overall exterior qualities than farther away ones.

\subsection{Third and Fourth Hypotheses: Distances from a Riverbank or Core}

More broadly, residents and owners of similar homes in a neighbourhood may have correlated reactions to not only the events and activities happening at nearby locations [43], but also the (dis-)amenities of those locations when deciding about investing time and money in their homes [50] [51].

Therefore, 3) a third hypothesis is for residents and owners located on or near a natural amenity such as a riverbank to have better-maintained homes than those farther away [31]. Owner-occupiers of larger homes may in particular be able to capitalize on the view from a riverbank, the recreational opportunities, and the possibly fresher environment. Note this predicted relationship would be reversed in the case of location near to a disamenity, such as an industrial riverbank. Better-maintained homes may consequently be located out-of-sight of an ugly riverbank, but within walking distance of access to the water.

Even more so, 4) residents and owners of homes located near to a downtown/core may be less willing and/or able to maintain them [31]. Their homes may not only be physically older and socially less-functional, but they may also be under pressure for transition to non-residential use. The fourth hypothesis is therefore for farther distance gradually insulating residents and owners from the effects of a downtown/core. Hence, the distancefrom-core effect will attenuate at an inverse rate as that of the distance-from-riverbank effect in the third hypothesis.

As already mentioned, these hypotheses are tested with data from a paper-and-pencil survey of the conditions of twelve exterior attributes of up to 800 individual houses that have been surveyed twice in each of four older-urban neighbourhoods in Windsor, Ontario. The operationalization of this survey is described in the next section. The residents and properties in four surveyed older-urban neighbourhoods are summarized in the section following that.

\section{Measurement of Housing Quality}

\subsection{Surveys of Housing Quality}

A practical need in the wake of the aforementioned societal and governmental reconsideration of older-urban housing during the 1970s, was the identification of substandard homes for publicly-funded rehabilitation. This need was met with a flourish of surveys of the conditions of the interior and exterior attributes of housing in older-urban neighbourhoods [52] [53]. Area-based funding programs however terminated during the mid-1980s, and ownership and maintenance of residential property reverted ideologically to a private responsibility [54]. 
Researchers and planners seem subsequently to have been less interested in identifying poor housing, and especially neighbourhoods of it.

An exception has been the recent interest in surveying exterior housing quality in developing areas where there is no real estate market [55] [56]. For example, the latter authors evaluated rural houses in Thailand based upon villagers' rank-ordering of photographs. The photographed houses varied in terms of size; number of storeys; type of window; state of repair; roof material; material of walls; whether walls were painted; and whether concrete-block walls had a finish.

A secondary reason for renewed interest in monitoring the conditions of older-urban neighbourhoods, and the houses within them, may be the availability of new internet technologies, such as Google Earth and Google Street View for remote surveying via online panoramas [57].

\subsection{The Survey of Exterior Housing Quality}

This study's survey is a paper-and-pencil rating of the overall conditions of twelve exterior attributes of a singledetached (-like) house from top to bottom. In addition to six aforementioned attributes of shingles and eavestroughs, windows and doors, and the foundation wall and ground around it, the survey rated the conditions of six more attributes of the conditions of the chimney, roofline and wall, soffit (an upside-down ledge underneath the roof overhang), exterior walls and their type(s), porch and outside stairs. The survey excluded exterior attributes, such as driveway and garage, which frequently are not visible from the front of older-urban houses; and others, such as trees and vegetation, which may have a seasonal appearance or be easily trimmed.

The condition of each of 10 attributes was measured on a five checkbox scale, unless the attribute was not visible or was absent. The first of five checkboxes for an attribute had appropriate word-descriptors for a "new" condition; the second checkbox, a "normal" condition; and then the third through fifth checkboxes, progressively deteriorating conditions. Research interest in below-normal houses rather than better ones was the reason for additional checkboxes on that side of normal.

For example, a house's visible shingles condition was rated as either "new" (scored 1); "normal” (2); "curling and lifting" if some shingles were uneven (3); "torn" if corners or pieces had fallen off, or their granular and asphalt surface was eroding (4); and "missing” if they had gaps in the interlocking pattern (5). A house's shingles that were not visible either on a flat roof or due to overhanging vegetation, were rated zero, and then this variable was set as system-missing.

Three checkbox scales measured the conditions of two remaining attributes of the ground within $2 \mathrm{~m}$ of the foundation wall, and the exterior stairs (just in case the former was more difficult to see, and the latter was rarely present). Each first checkbox had word-descriptors for a "best" condition, and then progressively poorer conditions in the next two checkboxes. For example, the ground within $2 \mathrm{~m}$ of the foundation had best drainage if it was "level or sloping away from the wall" (1); whereas it was poorer if it was "concrete but sloping towards the wall” (2), and even more so if it was "earth and sloping towards the wall” (3). A house either without a foundation wall, or with vegetation obscuring it, was rated zero, and this variable was set as system-missing.

\subsection{Calculation of Overall Exterior Housing Quality Percentage}

These attribute-condition ratings were further employed in calculating an overall exterior quality percentage for a surveyed house. This variable has a shorthand name of $\mathrm{pHQ}$, usually followed by the year of survey, e.g., pHQ2015. A negative or positive pHQ percentage is a weighted average of the ratings of visible conditions around the "normal" condition of each attribute.

That is, first, each attribute was assigned a subjective "weight" proportional to its structural importance and coverage on a house. Attribute importance weights ranged from unity for shingles, as these comprise the roof over one's head; to 0.10 for outside stairs, as only a minority of houses might have these.

Second, a house's weighted attribute-condition rating was not only rescaled around its normal condition, but also reversed in sign to have a positive better condition and a negative poorer condition.

The positive or negative sum of these weighted attribute-condition ratings was finally expressed as a positive or negative percentage. This percentage measured a house's observed overall condition in relation to the respective maximum and minimum sums of weighted "best" and "worst" possible conditions of its visible attributes; that is, excluding system-missing attributes.

Numerically, a house with normal overall exterior condition will have zero for its calculated pHQ percentage. 
In practice, however, this may be too precise with decimal numbers in calculations, and so, a house having a pHQ percentage between $(-10) \%$ and $10 \%$ is in the "normal range" for overall exterior quality.

A house with all of the poorest or the best attribute-conditions (not-system missing) has a $(-100) \%$ or $100 \%$ $\mathrm{pHQ}$, respectively. The expression as a percentage of summed attribute-condition ratings, after rescaling around normal conditions, therefore equalizes the relative contributions of the more numerous checkboxes for below-normal conditions with the single one for an above-normal condition. These pHQ percentages are on an interval scale, and so, probabilities of houses having particular exterior qualities may be calculated for ranges of pHQ percentages.

\subsection{Maps of Exterior Housing Quality}

In addition to statistical analyses of exterior housing qualities in this study's subsequent sections, summary data for geocoded houses are mapped online at

http://web2.uwindsor.ca/courses/sociology/phipps/agp/research/threegooglemaps.html\#GWCUShqmap

with Version 3 of Google maps in one of three examples of this application [58]. Almost instantaneous display of coloured pins for up to 800 houses on a map represents a significant upgrade over V.2, in which pins might have appeared sequentially on the screen in one browser, or in their classes in another (e.g., [59]). Also new is clicking on a pin to open a descriptive information window that displays a correctly-facing static street view panorama. Clicking on this image in an information window opens an appropriately-rotated dynamic street view panorama of the house. This may be recognized as simulating a proprietary Google map, though without all the links to nearby businesses etc. Instead, this pin map has a right panel enabling visualization of observations by location or time.

The legend of a map of overall exterior housing qualities displays the numbers of houses with classified "below normal”, "normal”, and "above normal” overall exterior qualities. A corresponding map legend for each house attribute, such as shingles condition, displays subtotals of houses with five or three nominal conditions. Five is coincidentally one more than the currently permitted maximum number of display styles in a fusion table application. This pin map has thus continued the same as V.2 to load data from external XML datafiles, and to classify houses' data with its own functions, instead of upgrading to a fusion table application.

All in all, 15 Google maps are currently programmed for plotting overall exterior qualities and selected attribute conditions of surveyed houses at different times in four older-urban neighbourhoods in Windsor, Ontario, named the Glengarry, Wellington-Crawford, University, and Sandwich (GWCUS) neighbourhoods.

\section{Older-Urban Neighbourhoods in Windsor, Ontario}

\subsection{Residents and Properties in Older-Urban Residential Neighbourhoods}

In general, the original homes in Canadian older-urban neighbourhoods are from just before or just after the First World War [60]. These have now aged while their natural environments have matured, so that daytime seediness may appear unsafe in darkness [61]. In fact, residents rate older-urban neighbourhoods as more frequently having unsafe attributes, including the physical upkeep and maintenance of their individual private properties in daylight and darkness, than are observed in newer-urban areas, and in newer- and older-suburbs, rural areas and small towns [57]. Residential maintenance and improvement may be stifled if their core locations are under pressure for redevelopment for higher density residential or commercial projects, or transition to adaptive non-residential uses [31] [50]. Excluding redevelopments for higher density projects, they still tend to have higher density housing and more mixed land uses with less spacing between them than in newer suburbs, rural areas or small towns [62].

Furthermore, older-urban neighbourhoods are more likely than elsewhere to contain non-residential land uses, including private and public facilities for patrons during the evening [63]. Some facilities will aid residents, such as job centres or missions; while others will cater to visitors, ranging from small taverns up to large urban casinos [64]. Even if residents' activities are not offensive, those of visitors may be if they are attracted to those facilities [65] [66].

Environmental differences do not fully explain why older-urban residents evidently experience or witness more crime and disorder than do residents elsewhere [67]-[71]. Higher rates of victimization in older-urban neighbourhoods are also attributable to concentrations of at-risk sub-populations with age, income and lifestyle 
constraints, and propensities for moving in and out of a neighbourhood [72]-[75].

In fact, residents of four older-urban neighbourhoods in Windsor, Ontario, if compared with those in the remainder of Metropolitan Windsor, are inferred to be statistically significantly more likely to be younger; poorer; unemployed; movers during the previous five years; unattached or in lone parent families; or visible minorities. They also were less likely to reside in single- or semi-detached houses; but if they did, these were more likely to be older pre1961-constructed homes in need of major repair.

Note these inferences are from analyses of 16 social, economic and environmental characteristics of residents and homes in the last three Canadian censuses. Older-urban residents and homes in Metro Windsor are located within 32 so-called dissemination areas (DAs) comprising the four older-urban neighbourhoods, named the Glengarry, Wellington-Crawford, University, and Sandwich (GWCUS) neighbourhoods. A DA is the smallest geographical area for which the Canadian Census publishes its quinquennial data in 2001, 2006 and 2011; and Metro Windsor DAs had an average of 602 residents in 2006 [76]. DAs comprising the GWCUS neighbourhoods may be isolated on an online map of eight summary indices of residents and properties in Metro Windsor at http://web2.uwindsor.ca/courses/sociology/phipps/agp/research/threegooglemaps.html\#Windsormap. The remainder of the metropolitan area is comprised of up to 629 DAs.

The aforementioned inferences are especially based upon seven variables for residents, their families or households with statistically significantly different mean percentages in 32 GWCUS DAs, compared with those for up to 629 remaining Metro Windsor DAs (at 1\% significance level). These differences were for percentages of: Unattached adults (GWCUS mean of $69 \%$ vs. $47 \%$ for remainder of Metro Windsor in 2006); Young adults aged $20-24$ years old ( $14 \%$ vs. $7 \%$ ); Families headed by a male or female lone parent ( $26 \%$ vs. $17 \%$ ); Residents five years or older who had moved into or within a DA during the past five years (59\% vs. 36\%); Adults 15 years or older who were unemployed during the past year (14\% vs. 8\%); Residents 20 years or older with a university degree ( $21 \%$ vs. $16 \%$ ); and Residents from visible minorities (34\% vs. $13 \%$ ).

Four variables of private occupied dwelling units also had statistically significantly different mean percentages for: Owner occupied (GWCUS mean of 31\% vs. 79\% for remainder of Metro Windsor in 2006); Single- or semi-detached houses (39\% vs. 80\%); Pre1961 constructed (59\% vs. 40\%); and Needing major repair (10\% vs. $6 \%)$. A remaining statistically significant variable with dollars as its units measured: Respondent-estimated median adult income during the year prior to census survey (GWCUS mean of $\$ 15,000$ vs. $\$ 29,000$ for remainder of Metro Windsor in 2006).

Note these reported summary statistics are from the 2006 census that included a one-in-five (20\%) random sample of households who were legally compelled to answer the so-called long form in addition to the short form required of all households. The 2006 (and 2001) summary statistics are coincidentally similar to those calculated with 2011 data from a one-in-six (17\%) sample of households who voluntarily answered the so-called national household survey with the same questions as on the previous long form.

\subsection{Housing Condition in Older-Urban Neighbourhoods}

Statistically significantly higher percentages of pre1961-constructed dwellings and those in need of major repair reiterate not only the older ages of especially single- and semi-detached homes in the GWCUS neighbourhoods, but also their need for rehabilitation. Routine maintenance and improvement of these almost-100-years-old homes may have lagged since the 1974-1982 period, when many were rehabilitated with the Residential Rehabilitation Assistance Program (RRAP) funded by the federal government with provincial and municipal contributions [60].

Eligibility for the RRAP inside a municipality-designated neighbourhood was based upon a substandard dwelling unit's fundamental deficiencies in heating and fire safety, plumbing and electrical systems, and structural components. An assumption was that expenditures for installations or repairs of basic facilities by owneroccupiers or landlords might never be recouped at the time of property sale or in a permissible rent increase. This justified forgivable amounts of loans or grants in programs such as the RRAP for levering residents' use of the funds plus investment of their own money.

For example, RRAP assistance for owners consisted of a loan up to $\$ 10,000$ per dwelling unit. The maximum loan forgiveness was $\$ 3750$ if a household had an annual income below $\$ 6000$, and if they continued to occupy the dwelling for more than five years. Corresponding RRAP assistance for landlords was based upon an actual rehabilitation expenditure of $\$ 10,000$ per dwelling unit producing the maximum forgivable amount of $\$ 3750$, 
with a ten-year forgiveness rate. Landlords had to agree to a rent ceiling that might be below that commensurate with the property improvements. They also were not permitted to create new dwelling units or to convert a building from non-residential to residential use.

\subsubsection{Example of Canadian Housing Rehabilitation during the 1970s}

Homes in a subarea of the Glengarry neighbourhood in Windsor, Ontario, which is one of four surveyed olderurban neighbourhoods, had their exterior and interior conditions evaluated for the RRAP during 1975-1980. This evaluation found that $96 \%$ of 113 single-detached houses were in need of repair at an average cost of \$4982; all 156 dwelling units in 78 duplexes at an average cost of \$3409; and 98\% of 250 dwelling units in 60 apartment buildings at an average cost of $\$ 2405$. The total estimated total cost of repairing these and a few other types of houses was $\$ 2.1$ million, of which $\$ 1.1$ million would be forgivable, and the balance repayable.

\subsubsection{Example of British Housing Rehabilitation during the 1970s}

Coincidentally during the same period, the United Kingdom had central government programs for rehabilitating older-urban neighbourhoods and their housing [77] [78]. A British Housing Action Area (HAA) resembled a Canadian RRAP area, though the British program had stronger social objectives.

For example, the town of Loughborough, UK, located in the English Midlands, is a post-1820s town with a current population of around 50,000. Though smaller than Windsor, Ontario, it otherwise is similar with its original economic base in heavy-industrial manufacturing, such as knitwear, cranes, locomotives and buses. Its economy is now centred on Loughborough University, and modern technological firms. Loughborough's HAA No. 1 is a five- to ten-minute walking distance from the downtown (online at

http://web2.uwindsor.ca/courses/sociology/phipps/courses/np/haa1.html). It was one of six areas in the inner part of the town identified in 1976 as suffering from structural, environmental and social defects. This HAA's population was and is approximately 3000 .

This HAA's three types of housing are privately-owned terraced houses built before the 1880s; owner-occupied semi-detached houses from the 1920s; and rented apartment-style public (social) housing from the 1960s. Residents of each type of housing are quite dissimilar, including working people from Asian-immigrant and Asian-English families with children in the first type; skilled workers in the second type; and the elderly in the third type.

The planning approach for existing private housing was the promotion of improvement and rehabilitation in the better subareas, together with widespread clearance and redevelopment in the poorer ones, while retaining a mixed land use. Improvement, Intermediate, and Repairs grants were provided to owner-occupiers of pre1961 houses for constructing or upgrading basic plumbing and heating amenities specified by right in the 1974 Housing Act. These improvements were designed to extend a dwelling's expected useful life by 30 years.

Improvement grants paid for substantial improvements and repairs to bring a pre1961 house up to a good statutory 10-point standard. The observed range of grants in the HAA was between $£ 2000$ and $£ 6000$, up to a possible maximum of $£ 8500$ as $65 \%$ of eligible expenses. (Note that two Canadian dollars for each Great Britain pound is an approximate exchange rate.) Example expenditures in the $£ 2000$ to $£ 4000$ range for visible exterior improvements included the construction of an interior bathroom, and associated demolition of outbuildings, and then reconstruction of kitchen and bathroom. Other visible exterior improvements costing from $£ 700$ to $£ 800$ included the front and rear application of silicone solution, and replacing the roof and eavestroughs; $£ 300$ to $£ 400$ for repointing of brickwork or chimney; and $£ 200$ for each replacement window or door.

Intermediate grants were for the installation of missing standard amenities and the associated repairs to bring a pre1961 house up to a reasonable standard. Repairs grants were for substantial repairs to pre1919 houses, and the HAA's observed grants averaged approximately £2000, up to possible maximum of $£ 4,000$ as $65 \%$ of eligible expenses. Individual visible exterior repairs were similar to those consolidated into an application for each of the other grants such as roof repair or re-slating; brick repointing, brickwork and silicone spray; new eavestroughs and downspouts; and window or door replacement.

\subsection{Four Survey Neighbourhoods}

As already mentioned, the Glengarry Neighbourhood is one of four older-urban neighbourhoods in Windsor, Ontario, where the exteriors of hundreds of single-detached houses and duplexes or triplexes resembling single-detached houses have been surveyed mostly since 2004 (Table 1). Houses in these older-urban neighbor- 
Table 1. Summary exterior housing qualities.

\begin{tabular}{|c|c|c|c|c|c|c|c|c|c|}
\hline \multirow[b]{2}{*}{ Variable } & \multirow[b]{2}{*}{ Statistic } & \multicolumn{2}{|c|}{$\begin{array}{c}\text { Glengarry } \\
\text { neighbourhood }\end{array}$} & \multicolumn{2}{|c|}{$\begin{array}{l}\text { Wellington-Crawford } \\
\text { neighbourhood }\end{array}$} & \multicolumn{2}{|c|}{$\begin{array}{c}\text { University } \\
\text { neighbourhood }\end{array}$} & \multicolumn{2}{|c|}{$\begin{array}{c}\text { Sandwich } \\
\text { neighbourhood }\end{array}$} \\
\hline & & 1994 & 2011 & 2004 & 2015 & 2006 & 2013 & 2009 & 2014 \\
\hline $\begin{array}{l}\text { Surveyed } \\
\text { houses }\end{array}$ & Number & 838 & 740 & 768 & 836 & 804 & 785 & 505 & 473 \\
\hline Overall & Mean & $1.8 \%$ & $-5.6 \%$ & $-1.1 \%$ & $-4.7 \%$ & $-0.7 \%$ & $-1.1 \%$ & $-6.5 \%$ & $-3.7 \%$ \\
\hline Exterior & Median & $-3.2 \%$ & $-7.9 \%$ & $-4.7 \%$ & $-7.4 \%$ & $-7.1 \%$ & $-5.6 \%$ & $-9.2 \%$ & $-9.2 \%$ \\
\hline $\begin{array}{l}\text { Housing } \\
\text { Quality }\end{array}$ & $\begin{array}{c}\text { Modal } \\
\text { class interval }\end{array}$ & $-10 \%$ to $0 \%$ & $-10 \%$ to $0 \%$ & $-10 \%$ to $0 \%$ & $-10 \%$ to $0 \%$ & $-10 \%$ to $0 \%$ & $-10 \%$ to $0 \%$ & $-10 \%$ to $0 \%$ & $-10 \%$ to $0 \%$ \\
\hline \multirow[t]{6}{*}{$(p H Q)$} & $\begin{array}{l}\text { Modal number } \\
\text { of houses }\end{array}$ & 230 & 199 & 213 & 246 & 204 & 232 & 112 & 110 \\
\hline & $\begin{array}{l}\text { Standard } \\
\text { deviation }\end{array}$ & $27.5 \%$ & $27.8 \%$ & $26.5 \%$ & $23.1 \%$ & $26.25 \%$ & $26.3 \%$ & $29.2 \%$ & $28.4 \%$ \\
\hline & Range & $186 \%$ & $200 \%$ & $168 \%$ & $181 \%$ & $163 \%$ & $171 \%$ & $184 \%$ & $167 \%$ \\
\hline & Range Division & $31.0 \%$ & $33.3 \%$ & $28.0 \%$ & $30.2 \%$ & $27.2 \%$ & $28.5 \%$ & $30.7 \%$ & $27.8 \%$ \\
\hline & Skewness & 1.1 & 0.9 & 1.3 & 1.3 & 1.3 & 1.6 & 0.9 & 1.4 \\
\hline & Kurtosis & 2 & 3.2 & 2.6 & 3.5 & 2.1 & 3.3 & 1.8 & 3.1 \\
\hline $\begin{array}{l}\text { Shingles } \\
\text { attribute }\end{array}$ & $\begin{array}{l}\text { Modal class } \\
\text { interval }\end{array}$ & $2=$ Normal & $2=$ Normal & $2=$ Normal & $2=$ Normal & $2=$ Normal & $2=$ Normal & $2=$ Normal & $2=$ Normal \\
\hline \multirow[t]{2}{*}{$\begin{array}{l}\text { Condition } \\
\text { (At01) }\end{array}$} & $\begin{array}{l}\text { Modal number } \\
\text { of houses }\end{array}$ & 414 & 334 & 405 & 406 & 351 & 396 & 220 & 178 \\
\hline & Probability & $49 \%$ & $45 \%$ & $53 \%$ & $49 \%$ & $44 \%$ & $50 \%$ & $44 \%$ & $38 \%$ \\
\hline $\begin{array}{l}\text { Siding/Exterior } \\
\text { Wall }\end{array}$ & $\begin{array}{l}\text { Modal class } \\
\text { interval }\end{array}$ & $2=$ Normal & $2=$ Normal & $2=$ Normal & $2=$ Normal & $2=$ Normal & $2=$ Normal & $2=$ Normal & 2 = Normal \\
\hline \multirow[t]{2}{*}{$\begin{array}{l}\text { Condition } \\
\text { (At062) }\end{array}$} & $\begin{array}{l}\text { Modal number } \\
\text { of houses }\end{array}$ & 489 & 285 & 400 & 482 & 459 & 438 & 261 & 269 \\
\hline & Probability & $58 \%$ & $39 \%$ & $52 \%$ & $58 \%$ & $57 \%$ & $56 \%$ & $52 \%$ & $57 \%$ \\
\hline
\end{tabular}

hoods may have prime locations for residents, as almost all houses are located within walking distances of the riverbank of the Detroit River. Some houses are also located within walking distances to downtown or a core, including the University of Windsor, whereas others are up to $2.5 \mathrm{~km}$ away. Even so, more than routine maintenance may now be required of older single- and semi-detached houses, even if many had lengthened useful lives of 30 years after owners were assisted with government grants and loans for home maintenance and improvement during the early-1980s.

\subsubsection{Glengarry Neighbourhood}

Glengarry (G) was the first surveyed older-urban neighbourhood in Windsor, Ontario, in 1994, when it had 838 houses. It was also the first resurveyed neighbourhood in 2011 when it had 740 houses. This neighbourhood begins approximately $0.6 \mathrm{~km}$ from downtown on the eastern side of Windsor's casino, and extends approximately $2 \mathrm{~km}$ east almost as far as Walkerville neighbourhood. Its northern boundary is Riverside Drive East, which runs along the riverbank, and its southern boundary is Wyandotte Street East. Surveyed houses are located in the 100to 500-blocks of twelve north-south avenues or streets, and in the 500- to 1500-blocks of up to four east-west avenues or streets.

Note that avenues or streets referred to as north-south in this and the next two neighbourhoods are more accurately NNW-SSE; and east-west avenues or streets are more accurately ENE-WSW. Note further that house numbers on north-south streets or avenues in these three neighbourhoods increase monotonically with increasing distance away from the riverbank of the Detroit River. Thus, house numbers and the city-blocks containing them are ordinal measures of distance from the riverbank. Houses are more precisely located approximately $0.1 \mathrm{~km}$ to $0.7 \mathrm{~km}$ from the riverbank. 


\subsubsection{Wellington-Crawford Neighbourhood}

The Wellington-Crawford (WC) neighbourhood had 768 surveyed houses during 2004, and 836 houses during 2015. This neighbourhood begins approximately halfway between downtown Windsor and the University of Windsor, and so, its farthest-west house is $1.8 \mathrm{~km}$ west from downtown, and its farthest-east house is $0.5 \mathrm{~km}$ west from downtown. It is located south of Riverside Drive West, and north of Wyandotte Street West, with a western boundary on McEwan Avenue, and an eastern boundary on Church Street. Surveyed houses are located in the 100- to 500-blocks of twelve north-south avenues or streets, and the 400-blocks of two short east-west streets named Karl Place and Vera Place. Houses have similar distances as in Glengarry from the riverbank.

\subsubsection{University Neighbourhood}

During 2006, 804 houses were surveyed in the University (U) neighbourhood, while 785 houses were resurveyed in 2013. This neighbourhood is also located south of Riverside Drive West, and it extends a couple of city-blocks farther south than Wyandotte Street West to Union and Rooney Streets. At least one house is located on the riverbank at $0 \mathrm{~km}$, while its farthest south house is approximately $1.5 \mathrm{~km}$ from the riverbank.

This taller and narrower neighbourhood than either G or WC includes houses in the 100- to 700-blocks of six avenues, which from west to east are named Randolph, Rankin, Partington, Bridge, Josephine and Campbell. Downtown Windsor is approximately $1.75 \mathrm{~km}$ from this neighbourhood's farthest east house on Campbell Avenue; and $2.9 \mathrm{~km}$ from its farthest west house on Randolph Avenue. Windsor's downtown is thus much farther from the U neighbourhood than it is from either G or WC. A more influential "core" for the U neighbourhood may be the nearby University of Windsor campus, from which Randolph Avenue is the nearest street. This neighbourhood was home to university faculty and staff until 10- to 15-years ago, since when much of its housing has been converted to student rentals.

\subsubsection{Sandwich Neighbourhood}

The Sandwich (S) neighbourhood is located west of the University of Windsor, beginning basically under the Ambassador Bridge; and 505 houses were surveyed there during 2009, and 473 houses were resurveyed in 2014. Note that boarded-up houses under the bridge, about which residents have long complained, are located adjacent to and outside of the study neighbourhood [79]. However, media reports about these boarded-up houses and other offensive events may have portrayed this neighbourhood as an undesirable place to live. For example, the 2009 survey-year coincided with two residents being shot [80], and other residents being arrested by police at a large night-time house-party [81].

Note differently to the first three neighbourhoods that this neighbourhood's north-south streets and road are more accurately NNE-SSW, and its east-west streets are more accurately ESE-WNW. Five north-south streets and road in the neighbourhood are, from west to east, Sandwich Street, Peter Street, Baby, Cross and Queen Street, King and Harris Street, and Bloomfield Road. The neighbourhood has five shorter east-west streets called Mill, Laforet, Tournier, Brock, and St. Antoine. The first three east-west streets are located within the 3200blocks of the north-south streets, and the second two in their 3300-blocks.

A further difference is that houses in the $\mathrm{S}$ neighbourhood are directionally transposed with reference to the local business core (of its original Sandwich municipality) and the riverbank in comparison with those in the first three neighbourhoods. First, its five north-south streets and road are parallel with the riverbank. A nearest surveyed house to the riverbank on Sandwich Street is approximately $0.15 \mathrm{~km}$ east of it, whereas a farthest surveyed house on Bloomfield Road is approximately $0.7 \mathrm{~km}$ east of it. Second, its house and city-block numbers increase monotonically with increasing distance from the local business core. Sandwich Post Office is an oldest core landmark, and the nearest surveyed house is approximately $0.05 \mathrm{~km}$ from it, and the farthest surveyed house, approximately $1.25 \mathrm{~km}$ south of it.

\subsection{Neighbourhood Surveying}

Houses in each neighbourhood were surveyed in the fall of the mentioned years by hundreds of undergraduate students enrolled in a second-year course in basic quantitative methods for the social sciences. Students were trained for surveying by looking at photographs of example single-detached houses, duplexes or duplex-like homes. Each student geocoded the longitude and latitude of a surveyed house's street address, and then keypunched these coordinates and the recorded exterior attribute data into a data template. Electronically-submitted data templates were error-checked, and compiled into a single datafile for each neighbourhood. 
Each house's PHQ overall exterior housing quality as a percentage above or below normal was calculated from its exterior attribute data using the aforementioned procedure. Also calculated were each house's straightline distances in kilometres from the riverbank and/or landmarks such as Windsor's downtown, the University of Windsor, or Sandwich Post Office.

\subsection{Descriptions of Exterior Housing Qualities}

\subsubsection{Central Tendencies Statistics}

A typical surveyed house in each of four older-urban neighbourhoods in Windsor, Ontario, had a normal overall exterior quality within the "normal range" between $(-10) \%$ and 10\% during both its first and second surveys (Table 1). For example, Sandwich neighbourhood houses’ pHQ2009s had a lowest mean $\mu_{\mathrm{pHQ} 2009}$ of $(-6.5) \%$, a median $\mathrm{Md}_{\mathrm{HQ} 2009}$ of $(-9.2) \%$, and a modal class of $(-10) \%$ to zero\% with 112 houses; and each of these central tendencies is within the "normal range" between $(-10) \%$ and $10 \%$.

However, S houses similarly to those in other surveyed neighbourhoods changed little on average through time. They however differed from houses in three remaining neighbourhoods with their slightly higher mean $\mu_{\mathrm{pHQ} 2014}$ of $(-3.65) \%$ than earlier in 2009, though with same median $\mathrm{Md}_{\mathrm{HQ} 2014}$ of $(-9.2) \%$, and (-10)\% to zero modal class as earlier in 2009. More representatively, for example, Wellington-Crawford neighbourhood houses' pHQ2015s had slightly lower mean $\mu_{\mathrm{pHQ} 2015}$ of $(-4.7) \%$ than $\mu_{\mathrm{pHQ} 2004}$ of $(-1.1) \%$; and lower median $\mathrm{Md}_{\mathrm{HQ} 2015}$ of (-7.4)\% in 2015 than $\mathrm{Md}_{\mathrm{HQ} 2004}$ of $(-4.7) \%$ in 2004; but with same (-10)\% to zero modal class for both surveys.

Modal "normal" conditions of houses' exterior attributes produced these typically-normal overall exterior qualities. For example, on average, 46\% of a neighbourhood's houses had "normal” visible shingles; and 54\% had "normal” siding/exterior walls, even though only 39\% of Glengarry houses had the latter condition in 2011.

\subsubsection{Variability Statistics}

Furthermore, the pHQs of houses in each neighbourhood had similar variabilities or dispersions as measured by their standard deviations and ranges between their maximum and minimum percentages. For example, S houses' pHQ2009s had a highest standard deviation $\sigma_{\mathrm{pHQ} 2009}$ of $29.2 \%$, and a range of $184 \%$, which is slightly less the maximum possible range of 200\%; whereas $181 \%$ was also the range of WC houses' pHQ2015s, although these had a lowest standard deviation $\sigma_{\mathrm{pHQ} 2015}$ of $23.1 \%$.

\subsubsection{Distributional Statistics}

Last, houses' pHQs in four neighbourhoods had additional similarities in their not-normal distributions that are positively skewed and/or more peaked-than-bell shaped. Positive skewness is indicated if a pHQ frequency distribution has a skewness statistic greater than unity, as this is above an acceptable range between $(-1)$ and 1 for symmetry; and correspondingly, $(-1)$ and lower indicates negative skewness. Likewise, a pHQ distribution is more peaked-than-bell shaped if its kurtosis statistic is greater than unity. The acceptable range is between (-1) and 1 for a bell shape, and so, less than (-1) indicates a flatter-than-bell shaped frequency distribution.

More peaked-than-bell shaped frequency distributions of houses' pHQs are especially confirmed with by-hand calculations of observed probabilities of up to one-third of houses in a neighbourhood having a pHQ percentage within the two bars comprising the $(-10) \%$ to $10 \%$ normal range.

In summary, a typical older-urban house had "normal" overall exterior quality at the times of its first and second surveys. Most surveyed houses were therefore neither irreparably deteriorated nor brand new. However, relatively more houses in each neighbourhood had calculated overall exterior qualities towards the poorest end of the scale than towards the best end of the scale; and this was especially the case for resurveyed houses. Usually at least one house in each neighbourhood had a calculated poorest or best overall exterior quality. In conclusion, therefore, typical overall exterior qualities of resurveyed houses in the three G, WC and U neighbourhoods - that is, except for the S neighbourhood-have almost certainly not changed for the better through time. The next section further tests hypotheses about average changes in overall exterior qualities of resurveyed houses.

\section{Change in Exterior Housing Quality through Time}

A house's exterior quality ultimately depends upon whether owners or residents do or do not care of it-and this study's first aforementioned hypothesis refers to this as a renovation- or deterioration-of-self effect. Houses age both physically and socially through time, and so, economic and environmental resources must be invested in 
order to prevent this ageing. Deterioration of a home's exterior through time would thus be hypothesised as the natural direction of change as it inexorably occurs in the absence of human action. Nevertheless, as already explained in the second section, owners and residents should be strongly motivated to maintain their economic and social investments in a home. The tested two-tailed research hypothesis is thus for either deterioration or improvement of exterior housing quality through time. This research hypothesis is tested with paired-samples tests of the same surveyed houses on selected streets at two points in time.

Surveyed houses on streets compose the analysed samples even though these houses were not randomly sampled (Table 2). In fact, houses on a street may be more similar to each other than they are to those on neighbouring streets. Houses on a street may have been built at the same time, in a particular style, or for a specific type of occupant. However, selection of streets' houses for analysis, as opposed to randomly-sampled houses, enables not only simple locational analysis but also replication of statistical analysis from one year to the next.

A paired, matched or related sample is required for temporal analysis, and this study's samples will be composed of the same "earlier" surveyed and "later" resurveyed houses. Houses have been resurveyed in the Glengarry (G) neighbourhood in 1994 and 2011, Wellington-Crawford (WC) neighbourhood in 2004 and 2015, University (U) neighbourhood in 2006 and 2013, and Sandwich (S) neighbourhood in 2009 and 2014. Operational matching of an earlier- and later-surveyed house by means of street address will always be imperfect due to construction of new houses, demolition of older ones, missing or obscured house numbers, and errors in reading or recording hundreds of house numbers. Hence, each neighbourhood has fewer matched houses than its totals described in the previous section: G has 520 matched houses, WC as 490, U has 622, and S has 305 (Table 2).

Hundreds of houses remain for analysis in each neighbourhood, and moreover, these matched houses have consistently-similar average overall exterior quality percentages with those of the total ones that are within the $(-10) \%$ to $10 \%$ normal range. In particular, neither noticeable deterioration nor improvement occurred on average between earlier-surveyed and later-resurveyed homes in U and S. The former's matched-houses' mean $\mu_{\mathrm{pHQ} 2006}$ of $(-0.7) \%$ is quite similar to their later mean $\mu_{\mathrm{pHQ} 2013}$ of $0.2 \%$; and likewise, the latter's matchedhouses' mean $\mu_{\mathrm{pHQ} 2009}$ of $(-2.5) \%$ is almost the same as their later mean $\mu_{\mathrm{pHQ} 2014}$ of $(-3.15) \%$.

In comparison, WC matched-houses' mean $\mu_{\mathrm{pHQ} 2004}$ of $(-0.5) \%$ may have slightly deteriorated to their later mean $\mu_{\mathrm{pHQ} 2015}$ of $(-3.7) \%$ in 11 years between resurveying. Only G's matched-houses' mean $\mu_{\mathrm{pHQ} 1994}$ of $2.3 \%$ may have significantly deteriorated to their later mean $\mu_{\mathrm{pHQ} 2011}$ of $(-5.9) \%$ during the longer 17-year period.

Note these statistics for populations of houses should have no theoretical statistical errors in their descriptions of average change in overall exterior housing qualities in four neighbourhoods. Populations however are composed of sampled houses on streets, and so, a locational question is whether the respective "no change" and "slight deterioration" in U or S and WC or G did or did not apply to overall exterior qualities of houses on particular streets. Houses on example streets are therefore analyzed as paired samples to test whether their overall exterior qualities were or were not representative of all houses through time.

These paired-samples temporal analyses are also complemented in a following subsection with independent-samples tests of differences between streets' mean overall exterior housing qualities in each year of their survey. This new test re-examines a finding about overall exterior housing qualities' especially deteriorating through time on streets near to a core while remaining the same on farther-away streets.

\subsection{Overall Exterior Housing Qualities on Selected Streets through Time}

Temporal changes in overall exterior housing qualities are compared for nearest and farthest streets to a downtown or local business core where the effect of that core may have been respectively largest or smallest on neighbourhood housing. For example, Aylmer Avenue is now G's farthest-west residential street, and thus, nearest to the casino and downtown Windsor. Too few houses remain for a testable sample on the farther west street, Glengarry Avenue, where many houses have been demolished since 1994 and replaced with open parking lots for casino patrons [82]. Seventeen additional houses were located on Aylmer Avenue in 1994 than in 2011, but 32 remaining as matched ones are more than 30 needed for a testable sample. These 32 matched houses' mean $\mathrm{x}_{\mathrm{pHQ} 1994}$ of $(-1.1) \%$, within the $(-10) \%$ to $10 \%$ normal range in 1994 , had significantly declined to a mean $\mathrm{x}_{\mathrm{pHQ} 2011}$ of $(-21.9) \%$, much below the normal range in 2011 (Table 2).

In contrast, 40 matched houses on Lincoln Road are examples of those on a farthest-east street in G, and they had stable average overall exterior qualities through time with mean $\mathrm{x}_{\mathrm{pHQ} 1994}$ of $(-1.25) \%$ and $\mathrm{x}_{\mathrm{pHQ}} 2011$ of $2.3 \%$. The paired-sample t-test in Table 2 affirms this road's lack of temporal change in mean overall exterior housing 
Table 2. Overall exterior housing qualities on selected streets in different years.

\begin{tabular}{|c|c|c|c|c|c|c|c|c|c|c|c|c|c|}
\hline \multirow[b]{3}{*}{ Variable } & \multirow[b]{3}{*}{ Statistic } & \multicolumn{6}{|c|}{ Glengarry neighbourhood } & \multicolumn{6}{|c|}{ Wellington-Crawford neighbourhood } \\
\hline & & \multicolumn{2}{|c|}{ All houses } & \multicolumn{2}{|c|}{ Aylmer avenue } & \multicolumn{2}{|c|}{ Lincoln road } & \multicolumn{2}{|c|}{ All houses } & \multicolumn{2}{|c|}{ McEwan avenue } & \multicolumn{2}{|c|}{ Janette avenue } \\
\hline & & 1994 & 2011 & 1994 & 2011 & 1994 & 2011 & 2004 & 2015 & 2004 & 2015 & 2004 & 2015 \\
\hline $\begin{array}{l}\text { Surveyed } \\
\text { houses }\end{array}$ & Number & 520 & 520 & 32 & 32 & 40 & 40 & 490 & 490 & 51 & 51 & 46 & 46 \\
\hline Overall & Mean & $2.3 \%$ & $-5.9 \%$ & $-1.1 \%$ & $-21.9 \%$ & $-1.3 \%$ & $2.3 \%$ & $-0.5 \%$ & $-3.7 \%$ & $-2.2 \%$ & $-0.9 \%$ & $4.1 \%$ & $-6.3 \%$ \\
\hline Exterior & Median & $-3.2 \%$ & $-7.8 \%$ & $-4.1 \%$ & $-19.3 \%$ & $-3.2 \%$ & $-4.2 \%$ & $-4.7 \%$ & $-7.3 \%$ & $-5.6 \%$ & $-3.2 \%$ & $-3.6 \%$ & $-10.15 \%$ \\
\hline \multirow[t]{7}{*}{$\begin{array}{c}\text { Housing } \\
\text { Quality (pHQ) }\end{array}$} & $\begin{array}{l}\text { Modal class } \\
\text { interval }\end{array}$ & $\begin{array}{l}-10 \% \\
\text { to } 0 \%\end{array}$ & $\begin{array}{l}-10 \% \\
\text { to } 0 \%\end{array}$ & $\begin{array}{l}-10 \% \\
\text { to } 0 \%\end{array}$ & $\begin{array}{c}-20 \% \\
\text { to }-10 \%\end{array}$ & $\begin{array}{l}-10 \% \\
\text { to } 0 \%\end{array}$ & $\begin{array}{l}-10 \% \\
\text { to } 0 \%\end{array}$ & $\begin{array}{l}-10 \% \\
\text { to } 0 \%\end{array}$ & $\begin{array}{l}-10 \% \\
\text { to } 0 \%\end{array}$ & $\begin{array}{l}-10 \% \\
\text { to } 0 \%\end{array}$ & $\begin{array}{l}-10 \% \\
\text { to } 0 \%\end{array}$ & $\begin{array}{l}-20 \% \\
\text { to } 10 \%\end{array}$ & $\begin{array}{l}-20 \% \\
\text { to } 0 \%\end{array}$ \\
\hline & $\begin{array}{c}\text { Modal } \\
\text { number of } \\
\text { houses }\end{array}$ & 158 & 148 & 13 & 11 & 17 & 11 & 142 & 134 & 14 & 16 & 11 & 22 \\
\hline & $\begin{array}{l}\text { Standard } \\
\text { deviation }\end{array}$ & $27.9 \%$ & $26.25 \%$ & $28 \%$ & $16.8 \%$ & $21.1 \%$ & $30.8 \%$ & $26.6 \%$ & $24.6 \%$ & $26 \%$ & $26.9 \%$ & $24 \%$ & $19.7 \%$ \\
\hline & Range & $186 \%$ & $200 \%$ & $142 \%$ & $71 \%$ & $109 \%$ & $134 \%$ & $168 \%$ & $181 \%$ & $113 \%$ & $137 \%$ & $96 \%$ & $101 \%$ \\
\hline & $\begin{array}{l}\text { Range } \\
\text { division }\end{array}$ & $31.0 \%$ & $33.3 \%$ & $23.7 \%$ & $11.8 \%$ & $18.2 \%$ & $22.3 \%$ & $28.0 \%$ & $30.2 \%$ & $18.8 \%$ & $22.8 \%$ & $16.0 \%$ & $16.8 \%$ \\
\hline & Skewness & 1.05 & 1.1 & 0.4 & -1 & 1.1 & 1.3 & 1.3 & 1.3 & 0.9 & -0.2 & 0.6 & 1.4 \\
\hline & Kurtosis & 1.9 & 3.6 & 1.6 & 1.3 & 2.3 & 1.4 & 2.4 & 3.2 & 0.5 & 1.1 & -0.5 & 2.7 \\
\hline Differences & Mean & & & & $-20.8 \%$ & & $3.5 \%$ & & & & $1.30 \%$ & & $-10.4 \%$ \\
\hline \multirow[t]{6}{*}{ between pHQs } & \multicolumn{2}{|c|}{ Standard deviation } & & & $25.3 \%$ & & $33.1 \%$ & & & & $26.1 \%$ & & $34.2 \%$ \\
\hline & \multicolumn{2}{|c|}{ Standard error } & & & $5 \%$ & & $5.2 \%$ & & & & $4 \%$ & & $5 \%$ \\
\hline & \multicolumn{2}{|c|}{ Observed T-statistic } & & & -4.6 & & 0.7 & & & & 0.36 & & -2.06 \\
\hline & \multicolumn{2}{|c|}{ Significance level } & & & 0.001 & & 0.5 & & & & 0.72 & & 0.05 \\
\hline & & \multicolumn{6}{|c|}{ University neighbourhood } & \multicolumn{6}{|c|}{ Sandwich neighbourhood } \\
\hline & & \multicolumn{2}{|l|}{$\begin{array}{c}\text { All } \\
\text { houses }\end{array}$} & \multicolumn{2}{|c|}{$\begin{array}{l}\text { Randolph } \\
\text { avenue }\end{array}$} & \multicolumn{2}{|c|}{$\begin{array}{l}\text { Campbell } \\
\text { avenue }\end{array}$} & \multicolumn{2}{|l|}{$\begin{array}{c}\text { All } \\
\text { houses }\end{array}$} & \multicolumn{2}{|c|}{$\begin{array}{c}\text { 3200-Block } \\
\text { including Mill, } \\
\text { Laforet \& } \\
\text { Tournier street }\end{array}$} & \multicolumn{2}{|c|}{$\begin{array}{l}\text { 3500- and } \\
\text { 3600-block }\end{array}$} \\
\hline Variable & Statistic & 2006 & 2013 & 2006 & 2013 & 2006 & 2013 & 2009 & 2014 & 2009 & 2014 & 2009 & 2014 \\
\hline $\begin{array}{l}\text { Surveyed } \\
\text { houses }\end{array}$ & Number & 622 & 622 & 101 & 101 & 93 & 93 & 305 & 305 & 96 & 96 & 102 & 102 \\
\hline Overall & Mean & $-0.7 \%$ & $0.2 \%$ & $1.13 \%$ & $1.15 \%$ & $-2.5 \%$ & $4.2 \%$ & $-2.5 \%$ & $-3.15 \%$ & $-5.9 \%$ & $-9.76 \%$ & $-0.06 \%$ & $2 \%$ \\
\hline Exterior & Median & $-7.1 \%$ & $-4.9 \%$ & $-4.1 \%$ & $-1.9 \%$ & $-7.3 \%$ & $-1.7 \%$ & $-6.75 \%$ & $-9.1 \%$ & $-8.6 \%$ & $-13.1 \%$ & $-4.45 \%$ & $-6.3 \%$ \\
\hline Housing & Modal & $-10 \%$ to & $-10 \%$ to & $-20 \%$ to & $-10 \%$ to & $-20 \%$ to & $-10 \%$ & $-10 \%$ to- & $-10 \%$ to & $-10 \%$ & $-10 \%$ to & $-10 \%$ to & $-20 \%$ to \\
\hline Quality (pHQ) & class interval & $0 \%$ & $0 \%$ & $-10 \%$ & $0 \%$ & $0 \%$ & to $0 \%$ & $0 \%$ & $0 \%$ & to $0 \%$ & $0 \%$ & $0 \%$ & $0 \%$ \\
\hline & $\begin{array}{c}\text { Modal } \\
\text { number of } \\
\text { houses }\end{array}$ & 193 & 159 & 23 & 34 & 38 & 27 & 68 & 71 & 25 & 21 & 24 & 42 \\
\hline & $\begin{array}{l}\text { Standard } \\
\text { deviation }\end{array}$ & $26.5 \%$ & $26.9 \%$ & $25.6 \%$ & $22.7 \%$ & $28 \%$ & $26.6 \%$ & $30.3 \%$ & $29.6 \%$ & $29.1 \%$ & $26.6 \%$ & $30.8 \%$ & $33.5 \%$ \\
\hline & Range & $163 \%$ & $156 \%$ & $162 \%$ & $135 \%$ & $141 \%$ & $149 \%$ & $184 \%$ & $167 \%$ & $164 \%$ & $157 \%$ & $155 \%$ & $165 \%$ \\
\hline & $\begin{array}{l}\text { Range } \\
\text { division }\end{array}$ & $27.2 \%$ & $26.0 \%$ & $27.0 \%$ & $22.5 \%$ & $23.5 \%$ & $24.8 \%$ & $30.7 \%$ & $27.8 \%$ & $27.3 \%$ & $26.2 \%$ & $25.8 \%$ & $27.5 \%$ \\
\hline & Skewness & 1.3 & 1.6 & 1 & 1.7 & 1.5 & 1.4 & 1.04 & 1.5 & 0.9 & 1.3 & 1.3 & 1.5 \\
\hline & Kurtosis & 2.1 & 3.2 & 1.7 & 4.6 & 2.3 & 2.5 & 1.6 & 2.9 & 2.1 & 3.1 & 2 & 2.2 \\
\hline Differences & Mean & & & & $0.03 \%$ & & $6.6 \%$ & & & & $-3.86 \%$ & & $2.1 \%$ \\
\hline between pHQs & Standard dev & viation & & & $29.9 \%$ & & $35.2 \%$ & & & & $31.8 \%$ & & $32.3 \%$ \\
\hline & Standard e & error & & & $4 \%$ & & $3.6 \%$ & & & & $3.3 \%$ & & $3.2 \%$ \\
\hline & Observed T-s & statistic & & & 0.008 & & 1.8 & & & & -1.19 & & 0.65 \\
\hline & Significance & e level & & & 0.99 & & 0.07 & & & & 0.24 & & 0.52 \\
\hline
\end{tabular}


quality between 1994 and 2011, as it fails to reject the null hypothesis of no change through time at 5\% significance level. This test also affirms the significant deterioration of houses' mean overall exterior quality on Aylmer Avenue, as the null hypothesis of no change through time is rejected at a significance level of 0.001 .

Note coincidentally Aylmer Avenue's matched houses' overall exterior housing qualities had a much narrower standard deviation $\mathrm{S}_{\mathrm{pHQ} 2011}$ of $16.8 \%$ in 2011 than $\mathrm{s}_{\mathrm{pHQ} 1994}$ of $28 \%$ in 1994, and half-as-wide range of $71 \%$ in 2011 than $142 \%$ in 1994. Note furthermore the negatively-skewed frequency distribution of this avenue's overall exterior housing quality percentages in 2011, as the skewness statistic is less than or equal to (-1). Hence, these statistics may indicate not only additional deterioration by 2011 of poorer houses on Aylmer Avenue in 1994. They may also indicate parallel deterioration of the better houses on the avenue since the beginning of the same period.

The Glengarry neighbourhood's location on the east side of downtown Windsor is mirrored by the west-ofdowntown location of the Wellington-Crawford neighbourhood; and so, also similarly, a farthest street from downtown in WC, McEwan Avenue, had no statistical change in average overall exterior housing qualities, whereas one of the nearest streets, Janette Avenue, had statistically-significant average deterioration at $5 \%$ sig-

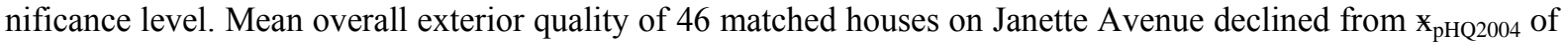
$4.1 \%$ to $\mathrm{x}_{\mathrm{PHQ} 2015}$ of $(-6.3) \%$, with comparable declines in $\mathrm{Md}_{\mathrm{pHQ} 2004}$ of $(-3.6) \%$ to $\mathrm{Md}_{\mathrm{pHQ} 2015}$ of $(-10.15) \%$, while retaining the same modal class of $(-20) \%$ to $(-10) \%$. In contrast on farther-away McEwan Avenue, 51 matched houses had similar earlier $\mathrm{x}_{\mathrm{pHQ} 2004}$ of $(-2.2) \%$ and later $\mathrm{x}_{\mathrm{pHQ} 2015}$ of $(-0.9) \%$, and $\mathrm{Md}_{\mathrm{pHQ} 2004}$ of $(-5.6) \%$ and $\mathrm{Md}_{\mathrm{pHQ} 2015}$ of $(-3.2) \%$.

Otherwise in two remaining neighbourhoods, average overall exterior quality percentages remained stable and within the normal range on the farthest-east and farthest-west avenues in U during 2006 to 2013; and on the farthest-north and far-south city-blocks in S during 2009 to 2014; and these were also similar to all houses in their respective neighbourhoods.

For example, 93 matched houses on Campbell Avenue and 101 matched houses on Randolph Avenue in U have respective $\mathrm{x}_{\mathrm{pHQ} 2006}$ of $1.13 \%$ and $(-2.5) \%$, and $\mathrm{x}_{\mathrm{pHQ} 2013}$ of $1.15 \%$ and $4.2 \%$. Both paired-sample t-tests fail to reject the null hypothesis, thereby affirming no average changes in overall exterior housing qualities on these two avenues through time. Note the further similarities in dispersion statistics of overall exterior housing qualities of houses on Campbell and Randolph Avenues in both 2006 and 2013. Residents in this neighbourhood should be insulated from the downtown core by their relatively far-away locations. They may however experience a converse "effect" of the University of Windsor, from which Randolph Avenue is the nearest street.

Similarly, average overall housing qualities near to or far from the core in the Sandwich neighbourhood had neither improved nor declined through time. Paired-sample t-tests affirm no statistical differences either between 96 matched houses' sample mean $\mathrm{x}_{\mathrm{pHQ} 2009}$ of $(-5.9) \%$ and $\mathrm{x}_{\mathrm{pHQ} 2014}$ of $(-9.76 \%)$ in S's farthest-north 3200-Block including Mill, Laforet and Tournier Streets; or between 102 matched houses' $\mathrm{x}_{\mathrm{pHQ} 2009}$ of $(-0.06) \%$ and $\mathrm{x}_{\mathrm{pHQ} 2014}$ of $2 \%$ in S's far-south 3500- and 3600-Blocks. Note however that average variabilities of these overall exterior housing qualities in S's 3200-Block+MLT had slightly narrowed from $\mathrm{s}_{\mathrm{pHQ}} 2009$ of $29.1 \%$ to $\mathrm{s}_{\mathrm{pHQ} 2014}$ of $26.6 \%$ through time, whereas those in S's 3500- and 3600-Blocks had slightly widened from $\mathrm{s}_{\mathrm{pHQ}} \mathrm{s}_{\mathrm{O}}$ of $30.8 \%$ to $\mathrm{S}_{\mathrm{pHQ} 2014}$ of 33.5\%.

\subsection{Overall Exterior Housing Qualities on Selected Streets at the Same Time}

The complementary results of analyses of differences between mean overall exterior housing quality percentages on the same streets or in the same city-blocks as in the previous subsection, but in the same year of their survey, are in Table 3. These analyses of houses as independent samples reiterate the emergence of differences not only between houses on Aylmer Avenue as a far-west street and those on Lincoln Road as the farthest-east street in the Glengarry neighbourhood since 1994; but also between houses in the farthest-north 3200-Block + MLT and those in the far-south 3500- and 3600-Blocks in the Sandwich neighbourhood during 2009 to 2014.

For example, Aylmer Avenue houses' sample mean $\mathrm{x}_{\mathrm{pHQ} 2011}$ overall exterior quality percentage of $(-17.6) \%$ in 2011 was from a statistical population with different mean of $\mu_{\mathrm{pHQ} 2011}$ than was Lincoln Road houses' sample mean $\mathrm{x}_{\mathrm{pHQ} 2011}$ of 7.8\%. The null hypothesis of these avenues' houses having been sampled from the same population is rejected at a significance level of 0.001 . (Note these statistical results remain the same after recalculating an observed value of $t$ that controls for two samples' statistically significantly unequal variances of overall exterior housing quality percentages at $4 \%$ significance level [83].) In 1994, in contrast, Aylmer Avenue and Lincoln Road houses' earlier $\mathrm{x}_{\mathrm{pHQ} 1994}$ of $(-3.2) \%$ and $(-2.6) \%$, respectively, were virtually the same, and they in fact were samples from the same statistical population with mean $\mu_{\mathrm{pHQ}} 1994$. 
Table 3. Overall exterior housing qualities on selected streets in same years.

\begin{tabular}{|c|c|c|c|c|c|c|c|c|c|c|c|c|c|}
\hline \multirow[b]{3}{*}{ Variable } & \multirow[b]{3}{*}{ Statistic } & \multicolumn{6}{|c|}{ Glengarry neighbourhood } & \multicolumn{6}{|c|}{ Wellington-Crawford neighbourhood } \\
\hline & & \multicolumn{3}{|c|}{1994} & \multicolumn{3}{|c|}{2011} & \multicolumn{3}{|c|}{2004} & \multicolumn{3}{|c|}{2015} \\
\hline & & $\begin{array}{c}\text { All } \\
\text { houses }\end{array}$ & $\begin{array}{c}\text { Aylmer } \\
\text { avenue }\end{array}$ & $\begin{array}{l}\text { Lincoln } \\
\text { road }\end{array}$ & $\begin{array}{c}\text { All } \\
\text { houses }\end{array}$ & $\begin{array}{l}\text { Aylmer } \\
\text { avenue }\end{array}$ & $\begin{array}{l}\text { Lincoln } \\
\text { road }\end{array}$ & $\begin{array}{c}\text { All } \\
\text { houses }\end{array}$ & $\begin{array}{l}\text { McEwan } \\
\text { avenue }\end{array}$ & $\begin{array}{l}\text { Janette } \\
\text { avenue }\end{array}$ & $\begin{array}{c}\text { All } \\
\text { houses }\end{array}$ & $\begin{array}{c}\text { McEwan } \\
\text { avenue }\end{array}$ & $\begin{array}{l}\text { Janette } \\
\text { avenue }\end{array}$ \\
\hline $\begin{array}{l}\text { Surveyed } \\
\text { houses }\end{array}$ & Number & 838 & 49 & 55 & 740 & 42 & 49 & 768 & 60 & 65 & 836 & 88 & 64 \\
\hline Overall & Mean & $1.8 \%$ & $-3.2 \%$ & $-2.6 \%$ & $-5.6 \%$ & $-17.6 \%$ & $7.8 \%$ & $-1.1 \%$ & $-1 \%$ & $3.1 \%$ & $-4.7 \%$ & $-2.7 \%$ & $-8.6 \%$ \\
\hline Exterior & Median & $-3.2 \%$ & $-3 \%$ & $-3.4 \%$ & $-7.9 \%$ & $-19.2 \%$ & $-3.9 \%$ & $-4.7 \%$ & $-6 \%$ & $-3.9 \%$ & $-7.4 \%$ & $-7.4 \%$ & $-11.7 \%$ \\
\hline $\begin{array}{c}\text { Housing } \\
\text { Quality }\end{array}$ & $\begin{array}{c}\text { Modal } \\
\text { class } \\
\text { interval }\end{array}$ & $\begin{array}{c}-10 \% \\
\text { to } \\
0 \%\end{array}$ & $\begin{array}{c}-10 \% \\
\text { to } \\
0 \%\end{array}$ & $\begin{array}{c}-10 \% \\
\text { to } \\
0 \%\end{array}$ & $\begin{array}{c}-10 \% \\
\text { to } \\
0 \%\end{array}$ & $\begin{array}{c}-20 \% \\
\text { to } \\
-10 \%\end{array}$ & $\begin{array}{c}-10 \% \\
\text { to } \\
0 \%\end{array}$ & $\begin{array}{c}-10 \% \\
\text { to } \\
0 \%\end{array}$ & $\begin{array}{c}-10 \% \\
\text { to } \\
0 \%\end{array}$ & $\begin{array}{c}-20 \% \\
\text { to } \\
-10 \%\end{array}$ & $\begin{array}{c}-10 \% \\
\text { to } \\
0 \%\end{array}$ & $\begin{array}{c}-10 \% \\
\text { to } \\
0 \%\end{array}$ & $\begin{array}{c}-20 \% \\
\text { to } \\
-10 \%\end{array}$ \\
\hline \multirow[t]{6}{*}{ (pHQ) } & $\begin{array}{c}\text { Modal } \\
\text { number of } \\
\text { houses }\end{array}$ & 230 & 13 & 20 & 199 & 13 & 11 & 213 & 16 & 14 & 246 & 28 & 16 \\
\hline & $\begin{array}{l}\text { Standard } \\
\text { deviation }\end{array}$ & $27.5 \%$ & $26 \%$ & $21.9 \%$ & $27.8 \%$ & $29.9 \%$ & $36.6 \%$ & $26.5 \%$ & $27.5 \%$ & $26.7 \%$ & $23.1 \%$ & $26.4 \%$ & $19.5 \%$ \\
\hline & Range & $186 \%$ & $142 \%$ & $120 \%$ & $200 \%$ & $177 \%$ & $137 \%$ & $168 \%$ & $125 \%$ & $120 \%$ & $181 \%$ & $152 \%$ & $110 \%$ \\
\hline & $\begin{array}{l}\text { Range } \\
\text { Division }\end{array}$ & $31 \%$ & $23.7 \%$ & $20 \%$ & $33.3 \%$ & $29.5 \%$ & $22.8 \%$ & $28 \%$ & $20.8 \%$ & $20 \%$ & $30.2 \%$ & $25.3 \%$ & $18.3 \%$ \\
\hline & Skewness & 1.1 & 0.7 & 0.6 & 0.9 & 1.3 & 1.1 & 1.3 & 1.01 & 0.7 & 1.3 & 0.3 & 1.2 \\
\hline & Kurtosis & 2 & 1.9 & 1.9 & 3.2 & 5.5 & 0.2 & 2.6 & 0.6 & 0.1 & 3.5 & 1.02 & 2.4 \\
\hline Differences & \multicolumn{3}{|c|}{ Difference between means } & $-0.7 \%$ & & & $-25.4 \%$ & & & -4.04 & & & $5.9 \%$ \\
\hline $\begin{array}{l}\text { between } \\
\text { sample }\end{array}$ & \multicolumn{3}{|c|}{$\begin{array}{l}\text { Standard error of } \\
\text { difference of means }\end{array}$} & $4.7 \%$ & & & $7.1 \%$ & & & $4.9 \%$ & & & $3.9 \%$ \\
\hline \multirow[t]{4}{*}{ pHQs } & \multicolumn{3}{|c|}{ Observed T-statistic } & -0.15 & & & $|-3.6|$ & & & $|-0.8|$ & & & -1.5 \\
\hline & \multicolumn{3}{|c|}{ Significance level } & 0.9 & & & 0.001 & & & 0.4 & & & 0.09 \\
\hline & & \multicolumn{6}{|c|}{ University neighbourhood } & \multicolumn{6}{|c|}{ Sandwich neighbourhood } \\
\hline & & \multicolumn{3}{|c|}{2006} & \multicolumn{3}{|c|}{2013} & \multicolumn{3}{|c|}{2009} & \multicolumn{3}{|c|}{2014} \\
\hline Variable & Statistic & $\begin{array}{c}\text { All I } \\
\text { houses }\end{array}$ & $\begin{array}{l}\text { Randolph } \\
\text { avenue }\end{array}$ & $\begin{array}{c}\text { Campbell } \\
\text { avenue }\end{array}$ & $\begin{array}{c}\text { All } \\
\text { houses }\end{array}$ & $\begin{array}{l}\text { Randolph } \\
\text { avenue }\end{array}$ & $\begin{array}{c}\text { Campbell } \\
\text { avenue }\end{array}$ & $\begin{array}{c}\text { All } \\
\text { houses }\end{array}$ & $\begin{array}{c}\text { 3200- } \\
\text { block } \\
\text { including } \\
\text { MLT } \\
\text { street }\end{array}$ & $\begin{array}{c}3500- \\
\text { and } \\
3600- \\
\text { block }\end{array}$ & $\begin{array}{c}\text { All } \\
\text { houses }\end{array}$ & $\begin{array}{c}\text { 3200- } \\
\text { block } \\
\text { including } \\
\text { MLT } \\
\text { street }\end{array}$ & $\begin{array}{c}3500- \\
\text { and } \\
3600- \\
\text { block }\end{array}$ \\
\hline $\begin{array}{l}\text { Surveyed } \\
\text { houses }\end{array}$ & Number & 804 & 140 & 115 & 785 & 140 & 105 & 505 & 129 & 216 & 473 & 151 & 133 \\
\hline Overall & Mean & $-0.7 \%$ & $0.3 \%$ & $-1.7 \%$ & $-1.1 \%$ & $0.12 \%$ & $3.7 \%$ & $-6.5 \%$ & $-9.7 \%$ & $-5.5 \%$ & $-3.65 \%$ & $-8.4 \%$ & $0.2 \%$ \\
\hline Exterior & Median & $-7.1 \%$ & $-6.1 \%$ & $-7.3 \%$ & $-5.6 \%$ & $-3.2 \%$ & $-1.7 \%$ & $-9.2 \%$ & $-11.6 \%$ & $-6.5 \%$ & $-9.2 \%$ & $-12 \%$ & $-6.75 \%$ \\
\hline $\begin{array}{l}\text { Housing } \\
\text { quality }\end{array}$ & $\begin{array}{c}\text { Modal } \\
\text { class } \\
\text { interval }\end{array}$ & $\begin{array}{l}-10 \% \\
\text { to } 0 \%\end{array}$ & $\begin{array}{l}-20 \% \text { to } \\
-10 \%\end{array}$ & $\begin{array}{c}-20 \% \text { to } \\
0 \%\end{array}$ & $\begin{array}{l}-10 \% \\
\text { to } 0 \%\end{array}$ & $\begin{array}{l}-10 \% \\
\text { to } 0 \%\end{array}$ & $\begin{array}{c}-10 \% \text { to } \\
0 \%\end{array}$ & $\begin{array}{l}-10 \% \\
\text { to } 0 \%\end{array}$ & $\begin{array}{c}-10 \% \text { to } \\
0 \%\end{array}$ & $\begin{array}{l}-10 \% \\
\text { to } 0 \%\end{array}$ & $\begin{array}{l}-10 \% \\
\text { to } 0 \%\end{array}$ & $\begin{array}{c}-10 \% \text { to } \\
0 \%\end{array}$ & $\begin{array}{c}-20 \% \\
\text { to } \\
-10 \%\end{array}$ \\
\hline \multirow[t]{6}{*}{$(p H Q)$} & $\begin{array}{c}\text { Modal } \\
\text { number } \\
\text { of houses }\end{array}$ & 204 & 36 & 38 & 232 & 47 & 28 & 112 & 30 & 55 & 110 & 34 & 32 \\
\hline & $\begin{array}{l}\text { Standard } \\
\text { deviation }\end{array}$ & $26.3 \%$ & $25 \%$ & $29 \%$ & $26.3 \%$ & $23.2 \%$ & $26.2 \%$ & $29.2 \%$ & $27.9 \%$ & $28.7 \%$ & $28.4 \%$ & $25.5 \%$ & $31.1 \%$ \\
\hline & Range & $163 \%$ & $162 \%$ & $141 \%$ & $171 \%$ & $137 \%$ & $149 \%$ & $184 \%$ & $164 \%$ & $174 \%$ & $167 \%$ & $157 \%$ & $165 \%$ \\
\hline & $\begin{array}{l}\text { Range } \\
\text { Division }\end{array}$ & $27.2 \%$ & $27 \%$ & $23.5 \%$ & $28.5 \%$ & $22.8 \%$ & $24.8 \%$ & $30.7 \%$ & $27.3 \%$ & $29.0 \%$ & $27.0 \%$ & $26.2 \%$ & $27.5 \%$ \\
\hline & Skewness & 1.3 & 1 & 1.5 & 1.6 & 1.7 & 1.3 & 0.9 & 0.9 & 1.2 & 1.4 & 1.3 & 1.5 \\
\hline & Kurtosis & 2.1 & 1.5 & 2.3 & 3.3 & 4.1 & 2.4 & 1.8 & 2.4 & 2.3 & 3.1 & 2.9 & 2.8 \\
\hline Differences & \multicolumn{3}{|c|}{ s Difference between means } & $1.9 \%$ & & & $-3.6 \%$ & & & $-4.2 \%$ & & & $-8.6 \%$ \\
\hline $\begin{array}{l}\text { between } \\
\text { sample }\end{array}$ & \multicolumn{3}{|c|}{$\begin{array}{c}\text { Standard error } \\
\text { of difference of means }\end{array}$} & $3.4 \%$ & & & $3.2 \%$ & & & $3.2 \%$ & & & $3.4 \%$ \\
\hline \multirow[t]{2}{*}{ pHQs } & \multicolumn{3}{|c|}{ Observed T-statistic } & 0.57 & & & -1.1 & & & -1.3 & & & -2.55 \\
\hline & Sign & ificance l & level & 0.6 & & & 0.26 & & & 0.18 & & & 0.01 \\
\hline
\end{tabular}


Similarly, the independent-samples t-test fails to reject the null hypothesis of no difference in 2009 between the sample mean $x_{\mathrm{pHQ}} 2009$ of $(-9.7) \%$ for houses in S's farthest-north 3200-block including Mill, Laforet and Tournier Streets, and $x_{\mathrm{pHQ}} 2009$ of $(-5.5) \%$ for houses in S's far-south 3500- and 3600-Blocks. Subsequently in 2014, however, a statistically-significant difference at $1 \%$ significance level had emerged between the former's virtually unchanged $\mathrm{x}_{\mathrm{pHQ} 2011}$ of $(-8.4) \%$ and the latter's slightly improved $\mathrm{x}_{\mathrm{pHQ} 2011}$ of $0.2 \%$. Note the statistically-similar variances of 3200-Block+MLT and 3500- and 3600-Block houses' overall exterior quality percentages at 5\% significance level, even though the former's standard deviation $\mathrm{s}_{\mathrm{pHQ}} 2014$ of $25.5 \%$ is somewhat less dispersed than the latter's $\mathrm{s}_{\mathrm{pHQ} 2014}$ of $31.1 \%$.

\subsection{Summary}

In summary, statistical tests have especially indicated significant differences in houses' overall exterior qualities on streets in the Glengarry and Wellington-Crawford neighbourhoods, and possibly in city blocks in the Sandwich neighbourhood. These tests have indicated the possible deterioration of houses through time near to downtown Windsor/the casino during the last decade-or-so, and near to the core of Sandwich between 2009 and 2014 , respectively, compared with the relative stability of farther-away houses. Interpretation of statistical results should be cautious, however, as these parametric hypothesis-testing procedures assume normal distributions of variables-and this is not the case for the selected road or avenues' overall exterior housing quality percentages (Table 2). At least one earlier- or later-surveyed street in each paired sample or independent sample had a frequency distribution that was more peaked-than-bell shaped and/or positively skewed, except for the negatively skewed pHQ2011s of Aylmer Avenue’s matched houses in 2011 (Table 2).

\section{Neighbouring Exterior Housing Qualities}

This study's second hypothesis of contagion-down-the-street in the quality of homes' exteriors assumes a resident or owner will react to whether their neighbours are or are not maintaining and improving their homes' exteriors. In particular, similar exterior qualities of neighbouring houses on a street would emulate an autoregressive process where individuals have engaged in correlated levels of exterior maintenance and improvement activities. A contagion-down-the-street effect might be positive or negative, but the result should be more similar exterior qualities of neighbouring houses than those farther away.

In technical terms, the second hypothesis is for spatially autocorrelated exterior housing qualities on a street. Autocorrelation is the statistical correlation of an observation in a time series or a spatial series with itself at different times or in different locations-that is, at different temporal or locational lags [84]. An autocorrelation coefficient is numerically similar to a bivariate correlation coefficient used in the next section, as it ranges from +1 for a perfect positive autocorrelation, through zero for no autocorrelation, to $(-1)$ for perfect negative autocorrelation.

The hypothesized autoregressive type of spatial autocorrelation resembles that of temporal autocorrelation between the rises and falls in the level of a lake through time. This is because the lake's level in one month or season will naturally be related to the level in the previous month or season, and so on. Even so, this relationship may be imperfect due to the occurrence of positive and negative "shocks" to the levels from one time period to the next. Positive and negative shocks might be caused respectively by abnormal rainfall or ice cover, and excessive evaporation or water usage.

The hypothesis is therefore for overall exterior housing qualities' rising in some subareas from a positive contagion-down-the-street effect, and falling in others from a negative effect-all the while relatively independently of the types and sizes of homes etc. and types of residents of those homes. There are, however, at least three methodological, theoretical, and operational complications in testing this hypothesis of autocorrelation in neighbouring overall exterior housing qualities.

First, spatial autocorrelation between neighbouring houses may be confounded by an underlying geographical trend in exterior housing qualities, such as, due to proximity to a riverbank or a core, as deduced in the third and fourth hypotheses. The standard method for elimination of a potential confounding trend is to "difference" the data in the time or spatial series. Hence, if $\mathrm{pHQ}_{\mathrm{i}}$ represents the overall exterior quality of an $\mathrm{i}^{\text {th }}$ house, then an autocorrelation coefficient is calculated between the difference between this $\mathrm{pHQ}_{\mathrm{i}}$ and its one neighbour's $\mathrm{pHQ}_{\mathrm{i}-1}$, and that between the $\mathrm{pHQ}_{\mathrm{i}}$ and its other neighbour's $\mathrm{pHQ}_{\mathrm{i}+1}$, and so on and so forth for remaining (N-i) houses. Note that hundreds of houses remain for analysis in each neighbourhood after one observation is lost in a once-differenced spatial series.

Second and more theoretically, the spatial autocorrelation of neighbouring overall housing exterior qualities 
may emulate an alternative moving average process. An analogous example of a moving average process is the temporal relationship between sale prices of homes in a neighbourhood where houses have different types and sizes etc. [85]. These physical differences between sold homes imply that, while one home's sale price may relatively increase or decrease another's sale price, it will only "move" the average sale price of homes in the neighbourhood.

Surveyed houses in this study may therefore be next door to different types and sizes of single-detached(-like) houses that, in violation of the assumption, are more or less likely to be maintained or improved. Neighbouring overall housing exterior qualities might thus have a smaller correlation with themselves than the correlation between the aforementioned shocks to their quality percentages either up or down around the average overall exterior housing quality in their neighbourhood [86]. A finding of this moving average process would however support the null hypothesis of no autoregression between neighbouring overall exterior housing qualities, as autoregressive and moving average processes are distinct models of autocorrelation.

Last and operationally, overall exterior housing quality percentages in each neighbourhood in each year do not comprise a single uninterrupted spatial series of observations. Rather, they are in subseries ordered by house number first on north-south streets, and then on west-east streets. Furthermore, surveyed single-detached(-like) houses within a subseries may have been next door to unsurveyed row houses, town houses or apartment buildings. In other words, a number of calculated differences between overall exterior housing qualities are not for neighbouring single-detached(-like) houses.

Nevertheless, two longest subseries have approximate averages of 131 ordered houses for six north-south avenues in the University neighbourhood, and 68 ordered houses on five north-south streets and road, plus two shorter east-west streets in the Sandwich neighbourhood. The autocorrelation coefficients for houses in these two neighbourhoods are quite similar to those for overall exterior housing qualities in the Glengarry and Wellington-Crawford neighbourhoods, even though the former averaged 46 houses in 16 subseries of avenues, streets and roads, and the latter averaged 56 houses in 14 subseries (Table 4).

Table 4. Autocorrelations between neighbouring overall exterior housing quality percentages.

\begin{tabular}{|c|c|c|c|c|c|c|c|c|c|}
\hline & & \multicolumn{2}{|c|}{$\begin{array}{c}\text { Glengarry } \\
\text { neighbourhood }\end{array}$} & \multicolumn{2}{|c|}{$\begin{array}{c}\text { Wellington-Crawford } \\
\text { neighbourhood }\end{array}$} & \multicolumn{2}{|c|}{$\begin{array}{c}\text { University } \\
\text { neighbourhood }\end{array}$} & \multicolumn{2}{|c|}{$\begin{array}{c}\text { Sandwich } \\
\text { neighbourhood }\end{array}$} \\
\hline & & 1994 & 2011 & 2004 & 2015 & 2006 & 2013 & 2009 & 2014 \\
\hline Variable & Statistic & All houses & All houses & All houses & All houses & All houses & All houses & All houses & All houses \\
\hline Surveyed houses & Number & 838 & 740 & 768 & 836 & 804 & 785 & 505 & 473 \\
\hline Overall exterior & Mean & $1.8 \%$ & $-5.6 \%$ & $-1.1 \%$ & $-4.7 \%$ & $-0.7 \%$ & $-1.1 \%$ & $-6.5 \%$ & $-3.65 \%$ \\
\hline \multirow[t]{3}{*}{$\begin{array}{c}\text { Housing } \\
\text { Quality (pHQ) }\end{array}$} & $\begin{array}{l}\text { Standard } \\
\text { deviation }\end{array}$ & $27.5 \%$ & $27.8 \%$ & $26.5 \%$ & $23.1 \%$ & $26.3 \%$ & $26.3 \%$ & $29.2 \%$ & $28.4 \%$ \\
\hline & Minimum & $-86 \%$ & $-100 \%$ & $-68 \%$ & $-81 \%$ & $-63 \%$ & $-71 \%$ & $-84 \%$ & $-67 \%$ \\
\hline & Maximum & $100 \%$ & $100 \%$ & $100 \%$ & $100 \%$ & $100 \%$ & $100 \%$ & $100 \%$ & $100 \%$ \\
\hline \multirow[t]{2}{*}{ Subseries } & Number & 16 & & 14 & & 6 & & 7 & \\
\hline & $\begin{array}{l}\text { Number } \\
\text { of houses }\end{array}$ & 46 & & 56 & & 131 & & 68 & \\
\hline Autocorrelation & Differencing & 1 & 1 & 1 & 1 & 1 & 1 & 1 & 1 \\
\hline \multirow[t]{5}{*}{ Coefficients } & Lag one & $-0.5^{\dagger}$ & $-0.5^{\dagger}$ & $-0.48^{\dagger}$ & $-0.52^{\dagger}$ & $-0.49^{\dagger}$ & $-0.59^{\dagger}$ & $-0.52^{\dagger}$ & $-0.45^{\dagger}$ \\
\hline & Lag two & 0.04 & 0.01 & 0.01 & 0.04 & $-0.08^{*}$ & $0.22^{\dagger}$ & 0.08 & -0.04 \\
\hline & Lag three & -0.05 & 0 & -0.03 & -0.02 & $0.13^{\dagger}$ & $-0.23^{\dagger}$ & -0.06 & -0.03 \\
\hline & Lag four & -0.01 & -0.02 & 0.03 & 0.03 & $-0.07^{*}$ & $0.17^{\dagger}$ & -0.01 & 0.02 \\
\hline & Lag five & 0.04 & 0.01 & -0.03 & -0.03 & 0.03 & $-0.12^{\dagger}$ & 0.05 & -0.00 \\
\hline
\end{tabular}

\footnotetext{
${ }^{\dagger}$ Statistically significant at $1 \%$ level or less. "Statistically significant at $5 \%$ level or less.
} 


\subsection{Autocorrelations between Neighbouring Overall Exterior Housing Quality Percentages}

The spatial autocorrelation coefficients summarized at lags one through five in Table 4 have the same signs and virtually the same magnitudes for once-differenced data in each of four neighbourhoods during each year of survey. Their magnitudes and signs however indicate a first-order moving average process describing changes in overall exterior housing qualities down the streets, and thus, not the hypothesized first-order autoregressive process ([87], p. 69]).

In detail, first, each autocorrelation at lag one is consistently negative and statistically significant at less than $1 \%$ level. This therefore indicates, for example, a positive difference between a house's exterior quality and one of its neighbouring ones will tend to be followed by a negative difference between that house and its other neighbouring one. Second, this autocorrelation at lag one is much larger as an absolute value than the frequently statistically-insignificant autocorrelations at lags two through five. This therefore indicates much less association between differences in exterior qualities for houses that are next-door-but-one, next-door-but-two, and so on. Note the lag one autocorrelations in the anomalous University neighbourhood in 2006 and 2013 would be statistically significant at a much lower significance level than the statistically-significant autocorrelations at lags two through five.

\subsection{Summary}

In summary, the spatially-autocorrelated differences between neighbouring overall exterior housing qualities in four older-urban neighbourhoods are not autoregressive, and thus, they are not representative of a contagiondown-the-street effect. Instead, they are autocorrelated in a moving average process where a positive difference between a house's overall exterior quality and its one neighbour tended to be followed by a negative difference between that house's overall exterior quality and that of its subsequent neighbour. In other words, overall exterior housing qualities did not rise from one house to the next in some subareas, and fall in other subareas. Rather, they oscillated around their de-trended average for their neighbourhood.

Notwithstanding, the conclusion is premature that each home's overall exterior quality in four older-urban neighbourhoods has not been helped or hindered by its neighbours' levels of exterior quality. This study's analysis has in particular two aforementioned operational complications in testing the hypothesis of spatial autocorrelation between neighbouring overall exterior housing qualities. These however may be resolved in future surveying of homes' exteriors by observing, first, the types and sizes of neighbouring single-detached(-like) houses, and second, the locations of unsurveyed row houses, town houses and apartment buildings.

\section{Exterior Housing Quality and Distance from the Riverbank}

This study's third hypothesis refines the first two about owners' and residents' activities for home maintenance and improvement by assuming they will be more willing and/or able to maintain or improve their home if it is located near to an environmental and recreational amenity such as a riverbank. As already hypothesized in the second section, this effect of a riverbank should extend farther into a neighbourhood beyond those residents who may have the best and most expensive homes located on the riverbank. Its moderate effect should be experienced by residents who are located farther away from the riverbank but who can see it from their home-and at a somewhat lower level by others who can walk to it from farther away. In other words, a one-tailed research hypothesis is for exterior housing quality to gradually decline with farther distance from a riverbank.

This one-tailed hypothesis may be too restrictive, however, as it fails to acknowledge an industrial riverbank's disamenity creating a possibly opposite relationship between exterior housing quality and distance from that riverbank. The tested two-tailed research hypothesis is therefore for overall exterior housing quality in surveyed neighbourhoods either deteriorating or improving with farther distance from the riverbank of the Detroit River. This research hypothesis is tested with bivariate correlation and regression.

Bivariate correlation and linear regression tests solely for a linear relationship between interval/ratio-scaled independent and dependent variables. The operational research hypothesis is thus for linear change in houses' overall exterior housing quality percentages in each neighbourhood with farther distance in kilometres from the riverbank. This research hypothesis is supported if the distance-from-riverbank independent variable has the negative bivariate correlation and the slope coefficient for declining overall exterior housing quality with farther 
distance from the riverbank, or positive ones for improving exterior quality with farther distance, but not zero ones for no change in exterior quality with farther distance.

\subsection{Houses' pHQs and Kilometres from the Riverbank: Correlation and Regression}

\subsubsection{Correlation Coefficients}

Two of eight simple linear regressions of overall exterior housing quality percentages on distances in kilometres from the Detroit Riverbank (DDRB) have statistically-significant correlation coefficients. Interestingly, both statistically significant findings are for houses in the Wellington-Crawford (WC) neighbourhood in 2004 and 2015 (Table 5). Its weak negative correlation coefficients of $r_{\text {WCPHQ2004,DDRB }}$ equal to $(-0.08)$ and $r_{\text {WCPHQ2015,DDRB }}$ equal to $(-0.07)$ are statistically significant at $5 \%$ level of significance-or-less with their correct degrees of freedom. These bivariate correlation analyses have many more potential degrees of freedom than the frequently tabled maximum of 90. The reported more precise levels of statistical significance have been calculated online with critical values of correlation coefficients for correct degrees of freedom.

Otherwise, statistically-insignificant bivariate correlations indicate no linear relationship between overall exterior housing qualities and distance from the riverbank in either the Glengarry (G) neighbourhood in 1994 and 2011, University (U) neighbourhood in 2006 and 2013, or Sandwich (S) neighbourhood in 2009 and 2014 (Table 5). Respective observed correlation coefficients ranging from $(-0.05)$ to 0.03 are virtually zero between overall exterior housing quality percentages and distances in kilometres from the riverbank. The null hypothesis of a zero/flat linear relationship is thus not rejected for three neighbourhoods' houses at time of their survey.

Table 5. Correlation and regression of overall exterior quality and distance from riverbank.

\begin{tabular}{|c|c|c|c|c|c|c|c|c|c|}
\hline & & \multicolumn{2}{|c|}{$\begin{array}{c}\text { Glengarry } \\
\text { neighbourhood }\end{array}$} & \multicolumn{2}{|c|}{$\begin{array}{c}\text { Wellington-Crawford } \\
\text { neighbourhood }\end{array}$} & \multicolumn{2}{|c|}{$\begin{array}{c}\text { University } \\
\text { neighbourhood }\end{array}$} & \multicolumn{2}{|c|}{$\begin{array}{c}\text { Sandwich } \\
\text { neighbourhood }\end{array}$} \\
\hline & & 1994 & 2011 & 2004 & 2015 & 2006 & 2013 & 2009 & 2014 \\
\hline Variable & Statistic & All houses & All houses & All houses & All houses & All houses & All houses & All houses & All houses \\
\hline Surveyed houses & Number & 838 & 740 & 768 & 836 & 804 & 785 & 505 & 473 \\
\hline Overall exterior & Mean & $1.8 \%$ & $-5.6 \%$ & $-1.1 \%$ & $-4.7 \%$ & $-0.7 \%$ & $-1.1 \%$ & $-6.5 \%$ & $-3.65 \%$ \\
\hline \multirow[t]{5}{*}{$\begin{array}{l}\text { Housing Quality } \\
\text { (pHQ) }\end{array}$} & Standard deviation & $27.5 \%$ & $27.80 \%$ & $26.5 \%$ & $23.1 \%$ & $26.3 \%$ & $26.3 \%$ & $29.20 \%$ & $28.40 \%$ \\
\hline & Minimum & $-86 \%$ & $-100 \%$ & $-68 \%$ & $-81 \%$ & $-63 \%$ & $-71 \%$ & $-84 \%$ & $-67 \%$ \\
\hline & Maximum & $100 \%$ & $100 \%$ & $100 \%$ & $100 \%$ & $100 \%$ & $100 \%$ & $100 \%$ & $100 \%$ \\
\hline & Skewness & 1.1 & 0.9 & 1.3 & 1.3 & 1.3 & 1.6 & 0.9 & 1.4 \\
\hline & Kurtosis & 2 & 3.2 & 2.6 & 3.5 & 2.1 & 3.3 & 1.8 & 3.1 \\
\hline Distance from & Mean & $0.31 \mathrm{~km}$ & $0.32 \mathrm{~km}$ & $0.53 \mathrm{~km}$ & $0.44 \mathrm{~km}$ & $0.7 \mathrm{~km}$ & $0.58 \mathrm{~km}$ & $0.43 \mathrm{~km}$ & $0.46 \mathrm{~km}$ \\
\hline \multirow[t]{5}{*}{ Riverbank in km } & Standard deviation & $0.13 \mathrm{~km}$ & $0.14 \mathrm{~km}$ & $0.2 \mathrm{~km}$ & $0.24 \mathrm{~km}$ & $0.4 \mathrm{~km}$ & $0.34 \mathrm{~km}$ & $0.14 \mathrm{~km}$ & $0.13 \mathrm{~km}$ \\
\hline & Minimum & $0.03 \mathrm{~km}$ & $0.03 \mathrm{~km}$ & $0.07 \mathrm{~km}$ & $0 \mathrm{~km}$ & $0 \mathrm{~km}$ & $0.01 \mathrm{~km}$ & $0.14 \mathrm{~km}$ & $0.15 \mathrm{~km}$ \\
\hline & Maximum & $0.6 \mathrm{~km}$ & $0.7 \mathrm{~km}$ & $0.85 \mathrm{~km}$ & $0.9 \mathrm{~km}$ & $1.5 \mathrm{~km}$ & $1.21 \mathrm{~km}$ & $0.71 \mathrm{~km}$ & $0.72 \mathrm{~km}$ \\
\hline & Skewness & -0.1 & 0.04 & -0.7 & -0.04 & 0.02 & 0.1 & -0.16 & -0.42 \\
\hline & Kurtosis & -0.8 & -0.6 & -0.65 & -1.25 & -1.15 & -1.1 & -0.67 & -0.26 \\
\hline \multirow[t]{5}{*}{ Regression } & Intercept & $0.2 \%$ & $-2 \%$ & $4.8 \%$ & $-1.8 \%$ & $-1.75 \%$ & $0.4 \%$ & $-7.7 \%$ & $-2.1 \%$ \\
\hline & Slope & $6.6 \%$ & $-11 \%$ & $-11.2 \%$ & $-6.6 \%$ & $1.6 \%$ & $-2.6 \%$ & $2.8 \%$ & $-3.3 \%$ \\
\hline & R-squared & $\begin{array}{l}\text { Less than } \\
1 \%\end{array}$ & $\begin{array}{c}\text { Less than } \\
1 \%\end{array}$ & $\begin{array}{c}\text { Less than } \\
1 \%\end{array}$ & $\begin{array}{l}\text { Less than } \\
1 \%\end{array}$ & $\begin{array}{c}\text { Less than } \\
1 \%\end{array}$ & $\begin{array}{c}\text { Less than } \\
1 \%\end{array}$ & $0 \%$ & $0 \%$ \\
\hline & $\begin{array}{l}\text { Correlation } \\
\text { coefficient }\end{array}$ & 0.03 & $|-0.05|$ & $|-0.08|$ & $|-0.07|$ & 0.025 & 0.03 & 0.01 & 0.01 \\
\hline & Significance level & NS & NS & 0.02 & 0.05 & NS & NS & NS & NS \\
\hline
\end{tabular}




\subsubsection{Intercept and Slope Coefficients}

Linear declines in overall exterior qualities of 768 houses in WC in 2004 and 836 houses in WC in 2015 with farther distance in kilometres from the Detroit Riverbank are indicated by the statistically-significant negative slopes of $\beta_{1 \mathrm{WCPHQ} 2004 \text {,DDRB }}$ equal to $(-11.2) \%$, and $\beta_{1 \mathrm{WCPHQ}} 2015, \mathrm{DDRB}$ equal to $(-6.6) \%$, respectively. Even so, a typical house's overall exterior quality would still be predicted in the normal $(-10) \%$ to $10 \%$ range at approximately-farthest $0.9 \mathrm{~km}$ from the riverbank in this neighbourhood: that is, at approximately $(-5) \%$ in 2004 and $(-8) \%$ in 2015. Also included in these calculations is the prediction from the intercepts of $\beta_{0 \mathrm{WC} \text { HQ2004,DDRB }}$ equal to $4 \%$ and $\beta_{0 \mathrm{WCPHQ}} 2015$,DDRB equal to $(-1.8) \%$ for normal exterior quality of a typical WC house located nearest to the riverbank in each survey year.

Note incidentally the similarity of both intercepts and slopes with the statistically-insignificant ones for $\beta_{0 \mathrm{GPHQ} 2011, \mathrm{DDRB}}$ of $(-2) \%$ and $\beta_{1 \mathrm{GPHQ} 2011, \mathrm{DDRB}}$ of $(-11) \%$, respectively, in the simple regression of overall exterior qualities of 740 houses in G in 2011 on their distances in kilometres from the Detroit Riverbank. Nonetheless, it has already been mentioned that the latter's correlation coefficient is not statistically significantly different from zero, similarly to those for the remaining simple regressions in U and S. Interpretation should therefore be cautious of this slope in G, even though it resembles the hypothesized one with overall exterior housing qualities linearly declining farther from the riverbank.

\subsection{Summary}

Statistically significant results from simple linear regressions have supported the distance-from-riverbank hypothesis for declining overall exterior housing qualities with farther distance in the Wellington-Crawford neighbourhood in 2004 and 2015, one of four older-urban neighbourhoods in Windsor, Ontario. Simple linear regression results supported this hypothesis because overall exterior housing qualities were, on average, normal for locations on or near the Detroit Riverbank, and then they deteriorated at a linear rate of between $7 \%$ and $11 \%$ for each kilometre farther away. Coincidentally, overall exterior housing qualities in another neighbourhood, the Glengarry neighbourhood in 2011, had a similar descriptive linear relationship with their distances from the Detroit Riverbank, although neither intercept nor slope was statistically significant.

No distance-from-riverbank effect has however been observed farther than a relatively short distance of 0.9 $\mathrm{km}$ from the riverbank, such as, in the University neighbourhood where farthest surveyed houses are located up to 1.2-to-1.5 km from the riverbank. This neighbourhood's overall exterior housing qualities neither improved nor deteriorated with linear distance from a riverbank in 2006 or 2013, similarly to those in the Sandwich neighbourhood in 2009 or 2014. These two neighbourhoods' overall exterior housing quality percentages were virtually uncorrelated with surveyed houses' distances in kilometres from the Detroit Riverbank.

In conclusion, therefore, further analysis is required of tentative findings of a statistically-significant distance-from-riverbank effect in one of four surveyed neighbourhoods, and none in the remainder. The aforementioned cautious interpretation of statistical results applies to parametric bivariate analyses unless tested dependent and independent variables have bivariate normal distributions. The bivariate distributions of overall exterior housing qualities and distances from the riverbank are not available, but observed distances in kilometres from the Detroit Riverbank have approximately normal univariate frequency distributions, with skewness statistics in the acceptable $(-1)$ to 1 range for symmetry, and kurtosis statistics in the acceptable range $(-1)$ to 1 range for a bell shape. In contrast, the univariate frequency distributions of overall exterior housing quality percentages in each survey year in each neighbourhood are both uniformly more-peaked-than-bell shaped with the kurtosis statistics greater than unity, and almost-uniformly positively-skewed with their skewness statistics greater than unity.

\section{Exterior Housing Quality and Distance from the Core}

This study's final hypothesis is for residents or owners to be less willing and/or able to maintain older and less functional homes, or ones under pressure for transition to non-residential use, if they are located nearer to a disamenity such as a downtown/core. This distance-from-core effect should attenuate in a neighbourhood at an inverse rate to that of a distance-from-riverbank effect. Houses should therefore have better exterior quality where they are newer and distant from the core. Even so, proximity to a core such as downtown may be an amenity for some residents who work there etc., and so, the two-tailed research hypothesis is for exterior housing quality either improving or deteriorating with farther distance from the core. This is tested with the same bivariate correlation and regression procedure as for a distance-from-riverbank effect in the previous section. 


\subsection{Houses' pHQs and Kilometres from the Core: Correlation and Regression}

\subsubsection{Correlation Coefficients}

Statistical results from five of eight simple regressions provide strong support for a research hypothesis about linear change in overall exterior housing quality with farther distance from a core (Table 6). Four simple regressions would furthermore support a specific research hypothesis for improving overall exterior housing quality with farther distance from that core. The anomaly is the highly statistically-significant negative bivariate correlation coefficient of $\mathrm{r}_{\mathrm{UpHQ} 2013, \mathrm{DD} \text { owntown }}$ equal to $(-0.13)$ for the University (U) neighbourhood's 785 houses' overall exterior qualities and distance from downtown Windsor in 2013.

Otherwise, two highly statistically-significant positive bivariate correlation coefficients are $\mathrm{r}_{\mathrm{GpHQ1994,DDowntown}}$ of 0.15 and $\mathrm{r}_{\mathrm{GpHQ}} 2011$,DDowntown of 0.19 for the Glengarry $(\mathrm{G})$ neighbourhood's 838 houses in 1994 and 740 houses in 2011, respectively. A third significant positive bivariate correlation at $2 \%$ significance level is

$\mathrm{r}_{\mathrm{WCPHQ} 2015, \mathrm{DD} o w n t o w n}$ of 0.08 for 836 houses' overall exterior qualities in the Wellington-Crawford (WC) neighbourhood in 2015.

The independent variable in each of these four regressions is a house's distance in kilometres from downtown Windsor, whereas the fifth regression's independent variable is distance in kilometres from the Sandwich Post Office in the core of the Sandwich (S) neighbourhood. In S in 2014, 473 overall exterior housing qualities had a marginally statistically-significant positive bivariate correlation of $\mathrm{r}_{\mathrm{SPHQ} 2014, \mathrm{DC} \text { ore }}$ equal to 0.094 with their distances from that core.

Table 6. Correlation and regression of overall exterior housing quality and distance from core.

\begin{tabular}{|c|c|c|c|c|c|c|c|c|c|}
\hline & & \multicolumn{2}{|c|}{$\begin{array}{c}\text { Glengarry } \\
\text { neighbourhood }\end{array}$} & \multicolumn{2}{|c|}{$\begin{array}{l}\text { Wellington-Crawford } \\
\text { neighbourhood }\end{array}$} & \multicolumn{2}{|c|}{$\begin{array}{c}\text { University } \\
\text { neighbourhood }\end{array}$} & \multicolumn{2}{|c|}{$\begin{array}{c}\text { Sandwich } \\
\text { neighbourhood }\end{array}$} \\
\hline & & 1994 & 2011 & 2004 & 2015 & 2006 & 2013 & 2009 & 2014 \\
\hline Variable & Statistic & All houses & All houses & All houses & All houses & All houses & All houses & All houses & All houses \\
\hline Surveyed houses & Number & 838 & 740 & 768 & 836 & 804 & 785 & 505 & 473 \\
\hline Overall exterior & Mean & $1.8 \%$ & $-5.6 \%$ & $-1.1 \%$ & $-4.7 \%$ & $-0.7 \%$ & $-1.1 \%$ & $-6.5 \%$ & $-3.65 \%$ \\
\hline \multirow[t]{5}{*}{$\begin{array}{l}\text { Housing Quality } \\
\text { (pHQ) }\end{array}$} & $\begin{array}{l}\text { Standard } \\
\text { deviation }\end{array}$ & $27.5 \%$ & $27.8 \%$ & $26.5 \%$ & $23.1 \%$ & $26.3 \%$ & $26.3 \%$ & $29.2 \%$ & $28.4 \%$ \\
\hline & Minimum & $-86 \%$ & $-100 \%$ & $-68 \%$ & $-81 \%$ & $-63 \%$ & $-71 \%$ & $-84 \%$ & $-67 \%$ \\
\hline & Maximum & $100 \%$ & $100 \%$ & $100 \%$ & $100 \%$ & $100 \%$ & $100 \%$ & $100 \%$ & $100 \%$ \\
\hline & Skewness & 1.1 & 0.9 & 1.3 & 1.3 & 1.3 & 1.6 & 0.9 & 1.4 \\
\hline & Kurtosis & 2 & 3.2 & 2.6 & 3.5 & 2.1 & 3.3 & 1.8 & 3.1 \\
\hline Distance from & Mean & $1.31 \mathrm{~km}$ & $1.44 \mathrm{~km}$ & $1.22 \mathrm{~km}$ & $1.17 \mathrm{~km}$ & $2.4 \mathrm{~km}$ & 2.05 km & $0.69 \mathrm{~km}$ & $0.61 \mathrm{~km}$ \\
\hline \multirow[t]{5}{*}{ Core in $\mathrm{km}$} & $\begin{array}{l}\text { Standard } \\
\text { deviation }\end{array}$ & $0.4 \mathrm{~km}$ & 0.37 km & $0.37 \mathrm{~km}$ & $0.36 \mathrm{~km}$ & $0.26 \mathrm{~km}$ & $0.16 \mathrm{~km}$ & $0.36 \mathrm{~km}$ & 0.31 km \\
\hline & Minimum & $0.57 \mathrm{~km}$ & $0.65 \mathrm{~km}$ & $0.51 \mathrm{~km}$ & $0.48 \mathrm{~km}$ & $1.76 \mathrm{~km}$ & 1.77 km & $0.02 \mathrm{~km}$ & $0.05 \mathrm{~km}$ \\
\hline & Maximum & $2.05 \mathrm{~km}$ & $2.1 \mathrm{~km}$ & $1.8 \mathrm{~km}$ & $1.77 \mathrm{~km}$ & $2.9 \mathrm{~km}$ & $2.4 \mathrm{~km}$ & $1.28 \mathrm{~km}$ & 1.27 km \\
\hline & Skewness & -0.2 & -0.2 & -0.3 & -0.15 & 0.05 & -0.02 & 0.01 & 0.4 \\
\hline & Kurtosis & -1.15 & -1.1 & -1.2 & -1.2 & -0.7 & -1.04 & -1.4 & -0.96 \\
\hline \multirow[t]{5}{*}{ Regression } & Intercept & $-12 \%$ & $-26 \%$ & $-0.1 \%$ & $-10.8 \%$ & $-8 \%$ & $43 \%$ & $-10 \%$ & $-8.9 \%$ \\
\hline & Slope & $10 \%$ & $14 \%$ & $-0.9 \%$ & $5.2 \%$ & $3 \%$ & $-22 \%$ & $5 \%$ & $8.6 \%$ \\
\hline & R-squared & $2 \%$ & $3.6 \%$ & $0 \%$ & $\begin{array}{l}\text { Less than } \\
1 \%\end{array}$ & $\begin{array}{l}\text { Less than } \\
1 \%\end{array}$ & $1.7 \%$ & $\begin{array}{c}\text { Less than } \\
1 \%\end{array}$ & $\begin{array}{c}\text { Less than } \\
1 \%\end{array}$ \\
\hline & $\begin{array}{l}\text { Correlation } \\
\text { coefficient }\end{array}$ & 0.15 & 0.19 & $|-0.01|$ & 0.08 & 0.03 & $|-0.13|$ & 0.065 & 0.094 \\
\hline & $\begin{array}{l}\text { Significance } \\
\text { level }\end{array}$ & 0.001 & 0.001 & NS & 0.02 & NS & 0.001 & NS & 0.05 \\
\hline
\end{tabular}


Three remaining statistically-insignificant bivariate correlations are virtually zero between overall exterior housing quality percentages and houses' distances in kilometres from the core in WC in 2004, U in 2006, and S in 2009. The null hypothesis of no linear relationship between variables is therefore not rejected for houses in three neighbourhoods at that time of their survey. Note again that distance to downtown Windsor is the independent variable in WC's and U's regressions, whereas S's regression has the distance to Sandwich Post Office located in that neighbourhood's own core.

\subsubsection{Intercept and Slope Coefficients}

Linear relationships between overall exterior housing qualities and distances from the downtown in G in 1994 and 2011 have not only similar statistically-significant correlations, but they also have similar regression slopes

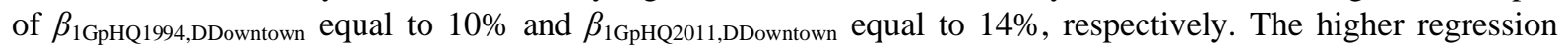
slope of $14 \%$ in 2011 than $10 \%$ in 1994 almost compensates with increasing distance from downtown for the lower intercept coefficient of $\beta_{0 \mathrm{GpHQ} 2011, \mathrm{DD} o w n t o w n}$ equal to (-26)\% in 2011 than $\beta_{0 \mathrm{GpHQ1994,DDowntown}}$ equal to (-12)\% in 1994. Hence, a typical farthest-east house in $\mathrm{G}$, located approximately $2 \mathrm{~km}$ from downtown, is predicted to have only slightly-changed overall exterior quality percentages of approximately 9\% in 1994 and $3 \%$ in 2011. Typical farther-away houses therefore retained their normal exterior quality.

In comparison, a nearest house located approximately 0.6 kilometres from downtown would be predicted to have deteriorated from approximately $(-6) \%$ within the normal range of $(-10) \%$ to $10 \%$ in 1994 , to much below this normal range at $(-17) \%$ in 2011.

Otherwise, typical overall exterior housing qualities in WC in 2004 and 2015, U in 2006, and S in 2009 and 2014, were predicted as remaining within the normal range between $(-10) \%$ and $10 \%$ at all distances from their cores, regardless of the statistical (in-)significance of their intercept or slope coefficients. For example, the minimum predicted overall exterior housing quality percentages at their respective nearest distances to a core would be approximately (-8)\% in WC in 2015, (-3)\% in U in 2006, and (-10)\% in S in 2009. Their intercepts and regression slope coefficients would correspondingly predict maximum overall exterior housing quality percentages around zero, such as, approximately (-2)\% in WC in 2004 and 2015 at farthest 1.8 km from downtown Windsor; 1\% in U in 2006 at farthest $2.9 \mathrm{~km}$ from downtown Windsor; and 2\% in S in 2014 at farthest $1.3 \mathrm{~km}$ from Sandwich Post Office.

Note the last prediction about overall exterior housing qualities in U in 2006 has interestingly been superseded by a different prediction in 2013. This is because U's simple regression of 2013 data has a negative slope of $\beta_{1 \mathrm{UpHQ} 2013, \mathrm{DD} o w n t o w n}$ equal to (-22)\% and a positive intercept of $\beta_{0 \mathrm{UpHQ} 2013, \text { DDowntown }}$ equal to $43 \%$. Hence, a typical farthest-west $U$ house located $2.4 \mathrm{~km}$ from downtown is predicted to have pHQ2013 of approximately $(-10) \%$; whereas a typical farthest-east house located at nearest $1.77 \mathrm{~km}$ from downtown, would have pHQ2013 of approximately 4\%. In other words, houses in U farther from downtown and thus nearer to the University of Windsor campus may have deteriorated since 2006. In comparison, those houses in U farther from campus and relatively nearer to downtown (though still absolutely far away) may have improved or stayed the same during this 2006 to 2013 period.

\subsection{Summary}

Statistical results from bivariate analyses of overall exterior housing qualities and houses' distances from a core in four older-urban neighbourhoods not only corroborate a first inference from temporal analysis in the fifth section about possible deterioration of houses nearer to a core such as downtown Windsor and its casino. They also introduce a second inference about possible deterioration of houses nearer to the University of Windsor.

First, typical overall exterior housing qualities in the Glengarry neighbourhood improved as hypothesised with farther distance from downtown in both 1994 and 2011. Even so, the regression intercept's much lower coefficient in 2011 than in 1994 predicted deterioration of houses located nearer to downtown during the period. Almost in compensation, however, the regression slope's larger coefficient in 2011 than in 1994 predicted relatively unaltered typical exterior quality of farther-away houses. Similarly in the Sandwich neighbourhood in 2014 and Wellington-Crawford neighbourhood in 2015, overall exterior housing qualities were poorer as hypothesized nearer to the downtown or local business core, and then they linearly improved farther away.

Second, overall exterior housing quality was unrelated to distance from downtown in the University neighbourhood in 2006, whereas it had a statistically-significant negative relationship in 2013. However, declining 
overall exterior quality with farther distance from downtown would in this neighbourhood equate with declining overall exterior quality nearer to the University of Windsor, as houses' distances to these two cores are inversely related. Houses in this neighbourhood have much nearer distances to the university campus than to downtown, and so, the former may be emerging as a core with a negative "effect" on them.

In conclusion, however, the foregoing statistically-significant linear relationships have relatively weak explanations of variations in overall exterior housing qualities. For example, the distance-from-core as independent variable accounts for less than four percent of the variation in that dependent variable. Moreover, the data have probably not satisfied the aforementioned requirement of bivariate normal distributions for parametric bivariate analyses. In particular, univariate frequency distributions of the dependent variable of overall exterior housing quality percentages are uniformly more peaked-than-bell shaped, and frequently positively skewed; whereas those of the independent variable of distances in kilometres to a core are frequently flatter-than-bell shaped.

\section{Conclusions}

\subsection{Summary}

The exteriors of hundreds of single-detached(-like) houses have been individually surveyed from public property in four older-urban neighbourhoods in Windsor, Ontario. Houses in these neighbourhoods have now been surveyed twice with the same instrument in the Glengarry neighbourhood in 1994 and 2011, Wellington-Crawford neighbourhood in 2004 and 2015, University neighbourhood in 2006 and 2013, and Sandwich neighbourhood in 2009 and 2014.

Each year's survey consisted of rating the visible conditions of up to 12 exterior attributes of houses during the fall. This study has in particular analysed the overall exterior housing quality percentages calculated from these exterior attribute-conditions. Percentages are on an interval scale from $(-100) \%$ for a house with poorest exterior quality; through $0 \%$ for normal exterior quality; up to $100 \%$ for best exterior quality.

Typical surveyed houses tended neither to have irreparable poor exterior quality, nor to be brand new. Average overall exterior housing quality percentages were within the "normal range" between $(-10) \%$ and $10 \%$, regardless of year of survey or year of resurvey. Standard deviations of these overall exterior housing quality percentages were slightly above or below $27 \%$. Approximately $95 \%$ of houses would thus have quality percentages between (-47)\% and 53\%-or approximately half-way between "poorest" and "normal", and "normal" and "best", respectively-if frequency distributions were normal.

In reality, however, frequency distributions of houses' quality percentages were rarely normal, and their average quality percentage was rarely zero percent for exactly "normal”. Rather, overall exterior housing quality percentages tended to have positively-skewed and more peaked-than-bell shaped frequency distributions. Cautious interpretation of subsequent univariate and bivariate statistical results has been the rule.

\subsection{Contribution to Theory}

Overall exterior qualities of houses on particular streets or in particular city blocks, and at different times, had different central tendencies and dispersion statistics than their neighbourhoods' consistent means within the $(-10) \%$ to $10 \%$ normal range and their standard deviations of approximately $27 \%$, respectively. They also did not necessarily have the "normal" modal condition of selected attributes in neighbourhoods. Four theoreticallydeduced hypotheses about the geographical and temporal variations in exterior housing quality within a neighbourhood have been summarized as a renovation- or deterioration-of-self effect, a contagion-down-the-street effect, a distance-from-riverbank effect, and a distance-from-core effect.

Univariate statistical tests of the renovation- or deterioration-of-self hypothesis were by means of differences between overall exterior housing qualities on streets and in city-blocks through time. These tests especially indicated a deterioration of homes through time if they were located near to Windsor's downtown and casino in one neighbourhood, and near to the local business core in another neighbourhood. In comparison, average overall exterior qualities of farther-away houses in both neighbourhoods had not changed for the worse or better during the same respective 17-year and 5-year periods of time.

Univariate and bivariate tests of the distance-from-core hypothesis further confirmed this deterioration in overall exterior housing quality near a disamenity, such as a core in three neighbourhoods, if compared with the relative stability of houses located farther away. In particular, houses nearest to downtown Windsor/casino in 
one neighbourhood had, on average, deteriorated to much below the $(-10) \%$ to $10 \%$ normal range for overall exterior quality at the time of their recent resurvey. However, even in this neighbourhood similarly to the other two, typical linear increases of approximately $5 \%$ to $14 \%$ for each farther kilometre from a downtown core predicted overall exterior qualities within the $(-10) \%$ to $10 \%$ normal range for houses farthest from that core.

Similarly, overall exterior housing qualities in the anomalous fourth neighbourhood were predicted to be within this normal range. They did this even though they linearly deteriorated with farther distance from the downtown core in the neighbourhood that is most distant from that core and possibly nearer to another one.

The hypothesis about a positive effect of an amenity such as a riverbank on individuals' maintenance and improvement of homes' exteriors was supported in one neighbourhood where coincidentally there was a weaker statistically-significant distance-from-core effect. An effect of distance from a riverbank may thus be neutralized by a distance-from-core effect wherever the latter is present. For example, overall exterior housing quality had no linear attenuation with distance from a riverbank in two additional neighbourhoods, even though homes were similarly located near to the natural riverbank; and moreover, homes in one of these neighbourhoods were located much farther distances away for a potentially more perceptible effect. Surveyed homes in the fourth remaining neighbourhood were located relatively nearer to an industrial riverbank that may have had a uniform effect on all of them.

Last, the hypothesis of an autoregressive contagion-down-the-street in overall exterior housing qualities was not supported by calculated autocorrelation coefficients for houses that were next-door neighbours, next-doorbut-one, next-door-but-two, and so on. Instead, differences in neighbouring overall exterior qualities tended to move around their neighbourhood's average overall percentage, and not rise and fall as if residents and owners had correlated levels of home maintenance and improvement. Future surveying of exclusively neighbouring single-detached (-like) houses should retest this contagion-down-the-street hypothesis. This study's aforementioned operational limitation in surveying was its inattention to types and sizes of neighbouring homes, and locations of unsurveyed row houses, townhouses and apartment buildings.

\subsection{Practical Implications}

On the one hand, this study's findings of "normal" average exterior housing quality in four neighbourhoods contradict a possible presumption of widespread deterioration of older-urban housing in Windsor, Ontario. On the other hand, however, these findings of average overall exterior housing quality in at least two neighbourhoods also include the deteriorating exterior quality of single-detached(-like) houses if they are located on streets or in city-blocks near to a disamenity such as downtown or another core, in comparison with better ones farther away.

Reasons have been theorized as to why proximity to a core would be a deterrent on exterior maintenance and improvement, whereas proximity to natural riverbank would be an incentive in locations farther from a core-but owners and residents have not been asked to verify these reasons. As mentioned in the introduction, this study's survey of single-detached (-like) houses' exteriors did not include interviews with residents and owners about maintenance and improvement of their homes.

In conclusion, home maintenance and improvement is an individual's responsibility, but property owners may need help from city officials and planners in doing this if their proximities to cores are inhibiting them. Coincidentally, when students are asked the question, "if average overall exterior qualities of neighbourhood houses are not improving through time, then this may require city officials and planners to?”, their most frequent answer is, "to provide financial assistance to lower-income owners and landlords in order to renovate those houses". Hopefully, city officials and planners will not assume one of three remaining answers is the correct one: "to prepare to demolish those houses"; "to encourage more house rentals to students"; or "to reprimand or penalize owners and landlords for neglecting those houses".

\section{Acknowledgements}

The author acknowledges the efforts of hundreds of undergraduate students at his university who through the years survey the houses reported in this study.

\section{References}

[1] Grzeskowiak, S., Sirgy, M.J., Lee, D.J. and Claiborne, C.B. (2006) Housing Well-Being: Developing and Validating a 
Measure. Social Indicators Research, 79, 503-541. http://dx.doi.org/10.1007/s11205-005-5667-4

[2] Potepan, M.J. (1989) Interest Rates, Income, and Home Improvement Decisions. Journal of Urban Economics, 25, 282-294. http://dx.doi.org/10.1016/0094-1190(89)90051-X

[3] Reschovsky, J.D. (1992) An Empirical Investigation into Homeowner Demand for Home Upkeep and Improvement. Journal of Real Estate Finance and Economics, 5, 55-71. http://dx.doi.org/10.1007/BF00153998

[4] Madeddu, M. (2013) Housing Quality and the Rescue of Failed Private Housing Schemes in England: A Policy Review. Journal of Housing and the Built Environment, 28, 567-578. http://dx.doi.org/10.1007/s10901-012-9328-z

[5] Clark, J. and Kearns, A. (2012) Housing Improvements, Perceived Housing Quality and Psychosocial Benefits from the Home. Housing Studies, 27, 915-939. http://dx.doi.org/10.1080/02673037.2012.725829

[6] Gifford, R. and Lacombe, C. (2006) Housing Quality and Children's Socioemotional Health. Journal of Housing and the Built Environment, 21, 177-189. http://dx.doi.org/10.1007/s10901-006-9041-x

[7] Mayer, N.S. (1981) Rehabilitation Decisions in Rental Housing: An Empirical Analysis. Journal of Urban Economics, 10, 76-94. http://dx.doi.org/10.1016/0094-1190(81)90024-3

[8] Winger, A. (1973) Some Internal Determinants of Upkeep Spending by Urban Home-Owners. Land Economics, 49, 474-479. http://dx.doi.org/10.2307/3145216

[9] Mendelsohn, R. (1977) Empirical Evidence on Home Improvements. Journal of Urban Economics, 4, 459-468. http://dx.doi.org/10.1016/0094-1190(77)90006-7

[10] Arnott, R., Davidson, R. and Pines, D. (1983) Housing Quality, Maintenance and Rehabilitation. Review of Economic Studies, 50, 467-494. http://dx.doi.org/10.2307/2297676

[11] Birch, D.L. (1971) Toward a Stage Theory of Urban Growth. Journal of the American Institute of Planners, 37, 78-87. http://dx.doi.org/10.1080/01944367108977361

[12] Dildine, L.L. and Massey, F.A. (1974) A Dynamic Model of Private Incentives to Housing Maintenance. Southern Economics Journal, 40, 631-639. http://dx.doi.org/10.2307/1056381

[13] Itard, L.C.M. and Klunder, G. (2007) Comparing Environmental Impacts of Renovated Housing Stock with New Construction. Building Research and Information, 35, 252-267. http://dx.doi.org/10.1080/09613210601068161

[14] Thomsen, A. and van der Flier, K. (2009) Replacement or Renovation of Dwellings: The Relevance of a More Sustainable Approach. Building Research And Information, 37, 649-659. http://dx.doi.org/10.1080/09613210903189335

[15] Judson, E.P., Iyer-Raniga, U. and Horne, R. (2014) Greening Heritage Housing: Understanding Homeowners’ Renovation Practices in Australia. Journal of Housing and the Built Environment, 29, 61-78. http://dx.doi.org/10.1007/s10901-013-9340-y

[16] Milstead, T.M. (2013) Residents Speak: Variables Influencing Home-Related DIY Decisions in the Former USSR; the Case of Vilnius, Lithuania. Journal of Housing and the Built Environment, 28, 113-128. http://dx.doi.org/10.1007/s10901-012-9289-2

[17] Özdemir Sarı, Ö.B. (2014) Empirical Investigation of Owner-Occupiers’ Reinvestments in Housing: The Case of Ankara, Turkey. Journal of Housing and the Built Environment, 29, 79-104. http://dx.doi.org/10.1007/s10901-013-9341-x

[18] Peng, T.C. (2013) An Institutional Economic Analysis of the Decision to Do-It-Yourself in Housing Renovation. Urban Studies, 50, 1796-1816. http://dx.doi.org/10.1177/0042098012468343

[19] Galster, G. (1983) Empirical Evidence on Cross-Tenure Differences in Home Maintenance and Conditions. Land Economics, 59, 107-113. http://dx.doi.org/10.2307/3145880

[20] Galster, G. (1987) Homeowners and Neighborhood Reinvestment. Duke University, Durham \& London.

[21] Phipps, A.G. (1983) Housing Renovation by Recent Movers into the Core Neighbourhoods of Saskatoon. The Canadian Geographer/Le Géographe Canadien, 27, 240-262. http://dx.doi.org/10.1111/j.1541-0064.1983.tb01477.x

[22] Baker, K. and Kaul, B. (2002) Using Multi-Period Variables in the Analysis of Home Improvement Decisions by Homeowners. Real Estate Economics, 30, 551-566. http://dx.doi.org/10.1111/1540-6229.00051

[23] Gosling, J.A., Keogh, G. and Stabler, M.J. (1993) House Extensions and Housing-Market Adjustment-A Case-Study of Wokingham. Urban Studies, 30, 1561-1576. http://dx.doi.org/10.1080/00420989320081501

[24] Munro, M. and Leather, P. (2000) Nest-Building or Investing in the Future? Owner-Occupiers’ Home Improvement Behaviour. Policy \& Politics, 28, 511-526. http://dx.doi.org/10.1332/0305573002501117

[25] Hills, S. and Worthing, D. (2006) Private Home, Public Cultural Asset: The Maintenance Behavior of Listed Building Owner-Occupiers. Journal of Housing and the Built Environment, 21, 203-213. http://dx.doi.org/10.1007/s10901-006-9043-8

[26] Chinloy, P.T. (1980) The Effect of Maintenance Expenditures on the Measurement of Depreciation in Housing. Jour- 
nal of Urban Economics, 8, 86-107. http://dx.doi.org/10.1016/0094-1190(80)90057-1

[27] Knight, J.R., Miceli, T. and Sirmans, C.F. (2000) Repair Expenses, Selling Contracts, and House Prices. Journal of Real Estate Research, 20, 323-336.

[28] Meijer, F., Itard, L. and Sunikka-Blank, M. (2009) Comparing European Residential Building Stocks: Performance, Renovation and Policy Opportunities. Building Research and Information, 37, 533-551. http://dx.doi.org/10.1080/09613210903189376

[29] Leather, P., Littlewood, A. and Munroe, M. (1998) Make Do and Mend? Explaining Home-Owners’ Approaches to Repair and Maintenance. The Policy Press, Bristol.

[30] Bogdon, A.S. (1996) Homeowner Renovation and Repair: The Decision to Hire Someone Else to Do the Project. Journal of Housing Economics, 5, 323-350. http://dx.doi.org/10.1006/jhec.1996.0017

[31] Plaut, P.O. and Plaut, S.E. (2010) Decisions to Renovate and to Move. Journal of Real Estate Research, 32, $461-484$.

[32] Littlewood, A. and Munro, M. (1996) Explaining Disrepair: Examining Owner Occupiers' Repair and Maintenance Behaviour. Housing Studies, 11, 503-525. http://dx.doi.org/10.1080/02673039608720872

[33] Montgomery, C. (1992) Explaining Home Improvement in the Context of Household Investment in Residential Housing. Journal of Urban Economics, 32, 326-350. http://dx.doi.org/10.1016/0094-1190(92)90022-D

[34] Shear, W.B. (1983) Urban Housing Rehabilitation and Move Decisions. Southern Economics Journal, 49, $1030-1052$. http://dx.doi.org/10.2307/1058105

[35] Mercer, J. and Phillips, D.A. (1981) Attitudes of Homeowners and Decision to Rehabilitate Property. Urban Geography, 2, 216-236. http://dx.doi.org/10.2747/0272-3638.2.3.216

[36] Pollakowski, H.O. (1988) The Determinants of Residential Renovation and Repair Activity. Final Report Prepared for the Office of Policy Development and Research, US Department of Housing and Urban Development, Washington DC.

[37] Gyourko, J. and Saiz, A. (2004) Reinvestment in the Housing Stock: The Role of Construction Costs and the Supply Side. Journal of Urban Economics, 55, 238-256. http://dx.doi.org/10.1016/j.jue.2003.09.004

[38] Baum, S. and Hassan, R. (1999) Home Owners, Home Renovation and Residential Mobility. Journal of Sociology, 35, 23-41. http://dx.doi.org/10.1177/144078339903500102

[39] Davidson, M. and Leather, P. (2000) Choice or Necessity? A Review of the Role of DIY in Tackling Housing Repair and Maintenance. Construction Management and Economics, 18, 747-756. http://dx.doi.org/10.1080/014461900433032

[40] Cirman, A., Mandič, S. and Zorić, J. (2013) Decisions to Renovate: Identifying Key Determinants in Central and Eastern European Post-Socialist Countries. Urban Studies, 50, 3378-3393. http://dx.doi.org/10.1177/0042098013482509

[41] Burby, R.J., Salvesen, D. and Creed, M. (2006) Encouraging Residential Rehabilitation with Building Codes: New Jersey's Experience. Journal of the American Planning Association, 72, 183-196. http://dx.doi.org/10.1080/01944360608976738

[42] Ioannides, Y.M. (2002) Residential Neighborhood Effects. Regional Science and Urban Economics, 32, 145-165. http://dx.doi.org/10.1016/S0166-0462(01)00082-5

[43] Boehm, T.P. and Ihlanfeldt, K.R. (1986) The Improvement Expenditures of Urban Homeowners: An Empirical Analysis. Journal of the American Real Estate and Urban Economics Association, 14, 48-60. http://dx.doi.org/10.1111/1540-6229.00368

[44] Harding, J.P., Rosenblatt, E. and Yao, V.W. (2009) The Contagion Effect of Foreclosed Properties. Journal of Urban Economics, 66, 164-178. http://dx.doi.org/10.1016/j.jue.2009.07.003

[45] Ahlbrandt, R.S. (1984) Neighborhoods, People, and Community. Plenum Press, New York and London. http://dx.doi.org/10.1007/978-1-4613-2711-0

[46] Brower, S. (1996) Good Neighborhoods: A Study of In-Town and Suburban Residential Environments. Praeger, Westport.

[47] Farrell, S.J., Aubry, T. and Coulombe, D. (2004) Neighborhoods and Neighbors: Do They Contribute to Personal WellBeing? Journal of Community Psychology, 32, 9-25. http://dx.doi.org/10.1002/jcop.10082

[48] McCulloch, A. (2003) An Examination of Social Capital and Social Disorganisation in Neighbourhoods in the British Household Panel Study. Social Science and Medicine, 56, 1425-1438. http://dx.doi.org/10.1016/S0277-9536(02)00139-9

[49] Caulfield, J. (1994) City Form and Everyday Life: Toronto’s Gentrification and Critical Social Practice. University of Toronto Press, Toronto.

[50] Helms, A.C. (2003) Understanding Gentrification: An Empirical Analysis of the Determinants of Urban Housing 
Renovation. Journal of Urban Economics, 54, 474-498. http://dx.doi.org/10.1016/S0094-1190(03)00081-0

[51] Poyner, B. (2006) Crime-Free Housing in the 21st Century. Jill Dando Institute of Crime Science, University College London, London.

[52] Duncan, T.L. (1971) Measuring Housing Quality: A Study of Methods. Occasional Paper No. 20, Centre for Urban and Regional Studies, The University of Birmingham, Birmingham.

[53] Kain, J. and Quigley, J. (1970) Measuring the Value of Housing Quality. Journal of the American Statistical Association, 65, 532-548. http://dx.doi.org/10.1080/01621459.1970.10481102

[54] Patterson, J. (1978) Distributional and Social Impacts of Canadian National Housing Policy: Leaving It to the Market. In: Bourne, L.S. and Hitchcock, J.R., Eds., Urban Housing Markets: Recent Directions in Research and Policy, University of Toronto Press, Toronto, 279-301.

[55] Pasha, H.A. and Butt, M.S. (1996) Demand for Housing Attributes in Developing Countries: A Study of Pakistan. Urban Studies, 33, 1141-1154. http://dx.doi.org/10.1080/00420989650011555

[56] Rindfuss, R.R., Piotrowski, M., Thongthai, V. and Prasartkul, P. (2007) Measuring Housing Quality in the Absence of a Monetized Real Estate Market. Population Studies, 61, 35-52. http://dx.doi.org/10.1080/00324720601103858

[57] Phipps, A.G. and Horrobin, B.A. (2014) Measuring Exterior Safety of Canadian Residential Neighbourhoods. Journal of Building Construction and Planning Research, 2, 132-149. http://dx.doi.org/10.4236/jbcpr.2014.22012

[58] Phipps, A.G. (2014) Three Applications of V.3 Google Maps: Just for Display of Data, or Analysis as Well? Journal of Geographic Information System, 6, 548-558. http://dx.doi.org/10.4236/jgis.2014.65045

[59] Phipps, A.G. (2011) Comparisons of Residents’ Perceptions of Patterns and Trends on Computer-Animated Maps and Graphs and on Google Maps of Events in Their Neighbourhoods. Cartographica, 46, 185-199.

http://dx.doi.org/10.3138/carto.46.3.185

[60] Carter, T. (1991) Neighbourhood Improvement: The Canadian Experience. In: Alterman, R. and Cars, G., Eds., Neighbourhood Regeneration: An International Experience, Mansell Publishing, London, 9-27.

[61] Samuels, R. (2005) After-Dark Design, Night Animation, and Interpersonal Interaction: Toward a Community-Security Paradigm. Journal of Architectural and Planning Research, 22, 305-318.

[62] Stucky, T.D. and Ottensmann, J.R. (2009) Land Use and Violent Crime. Criminology, 47, 1223-1264. http://dx.doi.org/10.1111/j.1745-9125.2009.00174.x

[63] Wilcox, P., Quisenberry, N., Cabrera, D.T. and Jones, S. (2004) Busy Places and Broken Windows? Toward Defining the Role of Physical Structure and Process in Community Crime Models. Sociological Quarterly, 45, 185-207. http://dx.doi.org/10.1111/j.1533-8525.2004.tb00009.x

[64] Grinols, E.L. and Mustard, D.B. (2006) Casinos, Crime and Community Costs. The Review of Economics and Statistics, 88, 28-45. http://dx.doi.org/10.1162/003465306775565756

[65] Felson, M. (2002) Crime and Everyday Life. 3rd Edition, Sage Publications, Thousand Oaks.

[66] Roncek, D.W. and Maier, P.A. (1991) Bars, Blocks, and Crimes Revisited: Linking the Theory of Routine Activities to the Empiricism of “Hot Spots”. Criminology, 29, 725-753. http://dx.doi.org/10.1111/j.1745-9125.1991.tb01086.x

[67] Andresen, M.A. (2006) A Spatial Analysis of Crime in Vancouver, British Columbia: A Synthesis of Social Disorganization and Routine Activity Theory. The Canadian Geographer/Le Géographe Canadien, 50, 487-502. http://dx.doi.org/10.1111/j.1541-0064.2006.00159.x

[68] Kohm, S.A. (2009) Spatial Dimensions of Fear in a High-Crime Community: Fear of Crime or Fear of Disorder? Canadian Journal of Criminology \& Criminal Justice, 51, 1-30. http://dx.doi.org/10.3138/cjccj.51.1.1

[69] Malczewski, J. and Poetz, A. (2005) Residential Burglaries and Neighbourhood Socioeconomic Context in London, Ontario: Global and Local Regression Analysis. The Professional Geographer, 57, 516-529. http://dx.doi.org/10.1111/j.1467-9272.2005.00496.x

[70] Nelson, A.L., Bromley, R.D.F. and Thomas, C.J. (2001) Identifying Micro-Spatial and Temporal Patterns of Violent Crime and Disorder in the British City Centre. Applied Geography, 21, 249-274. http://dx.doi.org/10.1016/S0143-6228(01)00008-X

[71] Wikström, P.O. and Dolmén, L. (1990) Crime and Crime Trends in Different Urban Environments. Journal of Quantitative Criminology, 6, 7-30. http://dx.doi.org/10.1007/BF01065287

[72] Cahill, M.E. and Mulligan, G.F. (2003) The Determinants of Crime in Tucson, Arizona. Urban Geography, 24, 582610. http://dx.doi.org/10.2747/0272-3638.24.7.582

[73] Mustaine, E.E. and Tewksbury, R. (1998) Predicting Risks of Larceny Theft Victimization: A Routine Activity Analysis Using Refined Lifestyle Measures. Criminology, 36, 829-857.

http://dx.doi.org/10.1111/j.1745-9125.1998.tb01267.x 
[74] Oh, J.H. (2003) Assessing the Social Bonds of Elderly Neighbors: The Roles of Length of Residence, Crime Victimization, and Perceived Disorder. Sociological Inquiry, 73, 490-510. http://dx.doi.org/10.1111/1475-682X.00068

[75] Robson, B., Lymperopoulou, K. and Rae, A. (2008) People on the Move: Exploring the Functional Roles of Deprived Neighbourhoods. Environment and Planning A, 40, 2693-2714. http://dx.doi.org/10.1068/a40241

[76] Statistics Canada (2014) Dissemination Area Reference Maps, by Census Tracts, for Census Metropolitan Areas and Census Agglomerations. Government of Canada, Ottawa. https://www12.statcan.gc.ca/census-recensement/2011/geo/map-carte/ref/ct-sr/index-eng.cfm

[77] Leather, P. (2000) Grants to Home-Owners: A Policy in Search of Objectives. Housing Studies, 15, 149-168. http://dx.doi.org/10.1080/02673030082333

[78] Wood, C. (1991) Urban Renewal: The British Experience. In: Alterman, R. and Cars, G., Eds., Neighbourhood Regeneration: An International Experience, Mansell Publishing, London, 44-69.

[79] Battagello, D. (2010) “Do Something”, Residents Plead; Action Urged on Derelict Buildings. The Windsor Star, A.1, 25 November 2010.

[80] Chen, D. (2009) Young Men Need to Change Their Ways. The Windsor Star, A.5, 2 March 2009.

[81] Thompson, C. (2009) Huge Frat Keg Party Leads to Arrests. The Windsor Star, A.1, 28 September 2009.

[82] Schmidt, D. (2013) City Reverses Decision to Ease up on Parking Lot Crackdown. The Windsor Star, A.1, 25 March 2013. http://blogs.windsorstar.com/news/city-reverses-decision-to-ease-up-on-parking-lot-crackdown

[83] Welch, B.L. (1947) The Generalization of “Student's” Problem When Several Different Population Variances Are Involved. Biometrika, 34, 28-35.

[84] Wei, W.S. (1990) Time Series Analysis: Univariate and Multivariate Methods. Addison-Wesley, Redwood City.

[85] Phipps, A.G. (2004) Crime and Disorder, and House Sales and Prices around the Casino Sites in Windsor, Ontario, Canada. The Canadian Geographer/Le Géographe Canadien, 48, 403-432. http://dx.doi.org/10.1111/j.0008-3658.2004.00068.x

[86] Chatfield, C. (1989) The Analysis of Time Series: An Introduction. 4th Edition, Chapman and Hall, New York.

[87] Kirchgässner, G., Wolters, J. and Hassler, U. (2013) Introduction to Modern Time Series Analysis. Second Edition, Springer, New York. http://dx.doi.org/10.1007/978-3-642-33436-8 